\title{
Effectiveness and cost-effectiveness of screening migrants for active and latent tuberculosis
}

(Commissioned title within SOA series:

Effectiveness and cost-effectiveness of screening migrants for active tuberculosis and latent tuberculosis infection: a narrative review of the evidence)

Dominik Zenner ${ }^{1,2,3}$, Hannah Hafezi ${ }^{1}$, Jessica Potter ${ }^{4}$, Susanna Capone ${ }^{5}$, Alberto Matteelli ${ }^{5}$

${ }^{1}$ Public Health England Colindale, Centre for Infectious Disease Surveillance and Control, London, UK

${ }^{2}$ University College London, Institute of Global Health, London, UK

${ }^{3}$ Imperial College London, National Institute for Health Research Health Protection Research Unit in Respiratory Infections, London, UK

${ }^{4}$ Barts and The London School of Medicine and Dentistry, Lizard Institute, Centre for Primary Care and Public Health

${ }^{5}$ Università degli Studi di Brescia, Department of Clinical and Experimental Sciences, Brescia, Italy

running head: TB and LTBI migrant screening

word count: 4,954

key words: TB case finding, LTBI screening, public health impact, effectiveness, cost effectiveness 


\section{Abstract}

With the advent of the WHO End-TB strategy there has been a renewed interest in screening for active tuberculosis (TB) and particularly latent TB infection (LTBI). In low incidence countries a high proportion of TB cases are notified amongst migrants, which often occurs due to LTBI reactivation. We aimed to review the effectiveness and cost-effectiveness of active and latent TB screening of migrants to inform and support the TB elimination strategy in low incidence countries. We carried out a narrative review of English language papers, published between 1 January 2000 and 31 June 2016 using PubMed. All studies which described effectiveness or costeffectiveness of active or latent TB screening amongst migrants were included. We identified 55 studies and included 40 for the effectiveness of screening, 11 for cost effectiveness and 4 , which reported both. Screening for active TB can be effective and cost effective depending on the setting, target group, and screening approach. Pre-entry screening programmes have some impact on receiving countries' epidemiology. The effectiveness and cost-effectiveness of LTBI screening as predicted in mathematical models is also highly setting specific with best potential results achieved if screening is restricted to high risk groups and/ or to migrants from highburden countries. 


\section{Introduction}

Tuberculosis (TB) is a significant contributor to the global burden of disease(1). In 2015 the World Health Organization (WHO) estimated about 10.4 million new cases of TB and 1.4 million TB deaths (2). Despite an incidence decline of 1.5\% between 2014-2015, TB remains an important cause of death globally(2). The End TB Strategy, ratified in 2014, sets out ambitious targets for global TB control including a 90\% reduction in TB incidence and a 95\% reduction in TB deaths globally by $2035(3)$. The strategy is based on three pillars: the first (integrated patientcentred care and prevention) outlines the importance of active case finding as a way to increase early TB diagnosis, and introduces for the first time screening for latent TB infection (LTBI) and preventative therapy among high-risk population groups as a key intervention.

The shift in migration patterns over the past 100 years has resulted in movement predominantly from countries with a high-burden of TB to low-burden countries, thus significantly impacting the TB epidemiology in low burden countries. Within these low burden, high migration countries a high proportion of new TB cases are now notified amongst the non-native population, and many of these cases arise after arrival in the host country, predominantly as a result of reactivation of $\operatorname{LBI}(4,5)$. Screening for TB can be divided into active case-finding of active disease or testing for LTBI, both of which are distinct from routine passive case-finding of active disease. Screening programmes for active TB have been used throughout most of this century and the last, although their focus and target populations have changed(6). In addition, and in keeping with the ambitious aim of TB elimination in low incidence countries, there has been an increasing interest in LTBI screening which has been included in national strategies $(7,8)$. 
The aim of this paper is to provide a review of the effectiveness and cost-effectiveness of screening for active TB and LTBI of migrants. The findings will inform public health policy going forward: improving TB control and working towards TB elimination in low incidence countries.

\section{Methodology}

We reviewed the literature for studies on the effectiveness and cost-effectiveness of screening for active TB and LTBI. The search terms are included in the appendix. Studies on effectiveness included those looking at yield, coverage and impact (e.g. incidence prevented)(9) as well as uptake and treatment completion. Cost effectiveness studies included cost benefit, cost utility and cost effectiveness studies. English language papers indexed on PubMed and published between 1 January 2000 and 31 June 2016 were included in the search. In addition we handsearched important review articles, guidelines and conference proceedings and added papers identified by experts in the field.

We pre-specified the following study types for inclusion: experimental studies (randomised controlled trials and quasi-randomised controlled trials); observational studies (retrospective and prospective cohort studies, case-control studies cross-sectional and case series); economic modelling studies and meta-analyses. Articles were included if they contained information on effectiveness or cost effectiveness of LTBI or active TB screening in migrants, defined as anyone who resides outside their country of birth, including refugees, asylum seekers and undocumented migrants.

Initial search results were imported into Zotero, then extracted into Excel (Microsoft Office for Mac 2011) and duplicates identified. The titles of the remaining articles were screened by HH for 
eligibility. The full text of those that fit the inclusion criteria were read and a final list of articles was identified by $\mathrm{HH}$ and reviewed by DZ. A total of 55 studies were identified with 40 appropriate for the effectiveness of LTBI and active TB screening, 11 appropriate for cost effectiveness of LTBI and active TB screening and 4 which reported both cost effectiveness and effectiveness of LTBI and active TB screening (figure 1).

A limited assessment of study quality and risk of bias was made using SIGN methodology(10). Data was extracted from papers on effectiveness of screening using the format detailed in table 1 and on cost-effectiveness of screening as detailed in table 2. Data were summarised as simple proportions and ranges - the variability of studies and study heterogeneity precluded metaanalysis of our data. 


\section{Active TB}

Screening for active TB has been common practice since the early and mid part of the $20^{\text {th }}$ century. Most of these activities have been aimed at detecting pulmonary TB, often across whole populations and mostly using Chest X-Rays (CXRs), supplemented by a symptom check (6). As early as in 1974, the WHO's Expert Committee on Tuberculosis recommended that indiscriminate TB case-finding by mobile mass radiography should be abandoned (11) due to reduced effectiveness and cost effectiveness, a consequence of changing TB incidence and altering epidemiology (12) (6). However, new guidelines on screening for active TB were developed in 2013 based on the evidence that screening, if done in the right way and targeting the right people, may reduce suffering and death(9). Although in the context of low and middle income countries the guidelines did not issue recommendations on screening migrants, it suggested that countries with a low burden of TB and an epidemic that is concentrated among specific risk groups - such as certain ethnic groups, prisoners, or homeless people - should focus their care and prevention efforts on these groups, and specifically mentioned migrants from high incidence countries as a priority group(13). This is supported by data from national experience for identified high risk groups, such as homeless persons (14) or migrants from high incidence countries (15).

Screening practices of migrants are highly variable in respect of policy, target population, the setting for screening and the type of tests used (16)(17). A number of factors influence the effectiveness and cost effectiveness of screening programmes including screening individuals from higher burden countries (18), use of screening methods with higher sensitivity and specificity (19) and the setting of screening (20).

\section{Effectiveness of active TB screening}


Most active TB screening programmes are primarily aimed at the detection of pulmonary TB, often with CXRs as the initial screening tool, sometimes augmented with or preceded by a symptom screen (16). A diagnostic test with high specificity, such as sputum culture should be used as follow-up to reduce the number of false positive results (21). Sputum smear has a low sensitivity and should not be the confirmatory test, although it is sometimes used(20). Clinically based diagnosis should only apply after all bacteriological testing has been exhausted.

Studies evaluating the properties and predictive values of different screening tests and algorithms suggest that initial screening with CXR followed by a highly specific confirmatory tests, such as the Gene Xpert or (if feasible), mycobacterial culture, have the highest predictive value and lowest numbers needed to screen (NNS) to detect active pulmonary TB (19). Clinical symptoms (such as prolonged cough) can be either used alone, in parallel with CXR or as an initial screen to identify those requiring CXR. Test properties vary with the background prevalence, sensitivities are between 65 and $90 \%$ for standardised combined symptom enquiry (ideally using scoring systems) with low specificity $(30-68 \%)(22,23)$. Initial symptom screens may be cheaper but have lower positive predictive values (PPV) and higher NNS than CXR-based programmes (24).

Sputum smear microscopy, although widely available, is limited by its relatively poor sensitivity and can lead to a high proportion of false negative results(25). Van't Hoog et al, when comparing screening algorithms highlight that both the NNS and predictive values are highly dependent on the TB prevalence in the screening setting, emphasising that choice of screening method should reflect the country demographic and epidemiology (20). Despite CXRs being 
used as a key method for screening, there is little clinical trial data to inform evidence based policy decisions.

Screening programmes can be administered pre-entry, on-entry or post-entry. Alvarez et al surveyed screening practices in high migration, low incident countries in 2008 and found that on-entry screening was undertaken by Norway, Switzerland and the UK (out of a total of 13) and often aimed at migrant sub-populations - for example limiting screening to migrants from countries with higher estimated TB incidence, or to high risk populations, such as refugees or asylum seekers (16). Some countries utilise post-arrival screening programmes, for example as a required component of access to specific services, in holding centres (26) or as follow up to pre-entry screening(27), and these are often limited to specific high risk target populations or settings(17). Pre-entry screening programmes are now used by a number of countries. In these programmes, screening is often mandatory, for example as part of the visa approval process(28)(29). Pre-entry screening can be carried out for recognised refugees often in neighbouring countries, but are usually not feasible for those who apply for asylum on arrival in the host country(28,30).

The coverage of active screening programmes varies, depending on the type of programme, the target group, and importantly, whether it is a voluntary or mandatory programme.

Unsurprisingly, mandatory pre-entry screening programmes have the highest coverage, usually approaching $100 \%(15)$. In programmes where screening is part of a prescribed procedure such as in migration reception centres, uptake is also very high (31-33). Interestingly Klinkenberg et al, after reviewing screening practices in EU/EEA countries (on-entry and post entry only), reported that the high coverage in mandatory programmes did not necessarily correlate with 
higher yields of TB identified (TB yield of $0.28 \%$ compared to $0.40 \%$ in voluntary screening) (15). Erkens et al reported on the Dutch experience of biannual screening post entry, demonstrating that coverage decreased from $59 \%$ in the second to $34 \%$ in the fifth round of successive screenings(34).

For screening programmes to be effective it is important to ensure that those who screen positive are linked into treatment, either in the national treatment programme overseas or domestically. There have been well documented difficulties with this for on-entry screening programmes $(35,36)$. It is possible that pre-entry screening strategies have some advantages if they are well linked into national treatment programmes(28).

Due to the significant heterogeneity of TB case definitions in different papers, the yield of active TB screening is difficult to assess and varies by target group/ country, type of migrant and setting of the programme (table 1). For bacteriologically confirmed TB, yields vary between 70 and approximately 1,600 per 100,000 (table 1). There is some evidence that pre-entry programmes have higher yields than on-entry and post entry programmes, although this review only included three countries with pre-entry screening. (15). Aldridge et al in their meta analysis of pre-entry screening programmes report higher yields amongst migrants from countries with a higher incidence of TB (18). Arshad et al also found higher yields among migrants from Africa or Asia compared to European migrants (three times and two times higher respectively (37).

Migrants are a heterogeneous group of individuals and the type of migrants screened also influences the yields of TB identified in screening programmes. For example Arshad et al identified a four times higher yield of TB cases among refugees compared to other migrants(37). 
The authors provided a number of potential explanations including the fact that refugees (where migration is forced) are less affected by the 'healthy migrant effect' than other groups of migrants. Other factors such as individual risk factors, such as previous contact to TB cases or a longer and more hazardous migration route or the quality of the screening programme can also influence the effectiveness of identifying TB cases through programmatic screening $(38,39)$.

There is a scarcity of evidence evaluating the impact of active TB screening on domestic TB incidence rates. A number of studies have compared screening yields with prevalent rates in migrants in the recipient country $(21,25)$. Liu et al reported that following the introduction of a culture based pre-entry screening programme there was a $40 \%$ decrease in the number of TB cases among migrants in the USA within 1 year of arrival (21). The UK reported a similar trend, demonstrating decreasing numbers of prevalent pulmonary TB cases as numbers of pulmonary TB cases found overseas increase $(25,38)$. Since these CXR-based programmes only detect pulmonary cases, their relative impact relates to the epidemiology in the recipient country. In the UK, where almost three quarters (73\%) of cases occur amongst the non UK-born population and where the majority of cases are extra-pulmonary, domestically notified cases were reduced by $6 \%$ through pre-entry screening, although almost all prevalent pulmonary cases had been detected(25). Some studies modelled the number of TB cases averted following implementation of pre entry screening programmes. Dasgupta et al identified that pre-entry screening in Canada was more successful at reducing domestic TB case notifications within one year of arrival compared to post-entry surveillance of migrants with latent TB (40). Wingate et al. reported even higher numbers of TB cases averted in their model, 157 cases annually, through pre-entry screening among students from China and India studying in the USA (41). Most cross- 
sectional studies analysing on-entry screening for migrant sub-populations are relatively smallscale, focus on the target population and do not analyse the impact on incidence (table 1).

\section{Cost Effectiveness of active TB screening programmes}

Evidence on cost effectiveness for active TB screening initiatives is also surprisingly limited. We have not found any studies, which calculate costs per quality adjusted life years (QALYs) for these active screening programmes. Most evidence comes from mathematical modelling studies, where active case finding is either presented as part of a more complex intervention (e.g. an LTBI screening programme with point-prevalent cases) (42) or is setting specific (e.g. to inform a potential expansion of USA pre-entry screening to Indian and Chinese students)(41). Furthermore, the generalisability of such findings may be limited. The outcome of interest is also heterogeneous - ranging from a simple cost analysis (43)to the cost per number of detected cases(41). The findings are often very context specific and cost effectiveness is estimated from a health system perspective. This is particularly relevant for programmes where part or all of the costs are borne by the screening recipient - as is common practice in pre-entry screening. Within this limited literature a number of studies found that screening for active TB was costeffective or even cost-saving from a recipient country perspective (table 2 ) in a range of different settings although more research is evidently required on this topic.

\section{Latent TB infection}

LTBI screening is aimed at detecting individuals who are asymptomatic but have a risk of progression to active TB in the near or remote future. Although there is a wide variation of settings and policies around LTBI screening and treatment for migrants, usually programmes are voluntary for participants whilst complex ethical considerations of mandatory screening are of 
concern(44). The observed effectiveness and estimated cost-effectiveness of LTBI screening not only depends on test and treatment specific variables, model assumptions and economic perspective but also behaviour-specific variables, such as test and treatment uptake and treatment completion (figure 2)(45).

Most authors recognise the importance of tackling LTBI in order to improve TB control. In a number of low incidence countries, including in Europe, a large proportion of TB occurs among migrant populations, often a considerable time after entry to the country(4). This observation together with the fact that molecular clustering among migrants is relatively low(46)is often seen as evidence of the importance of LTBI reactivation to explain these foreign born cases.

\section{Effectiveness of LTBI screening}

Diagnostic accuracy of $L T B I$ tests

It is not possible to directly measure latent TB infection. The three currently commercially available tests - tuberculin skin test (TST) and two interferon gamma release assays (IGRA), QunatiFERON and T-SPOT.TB - test a human immune response to Mycobacterial antigens. The TST is applied through an intradermal injection of $0.1 \mathrm{ml}$ purified protein derivative tuberculin and the size of the potential induration is read $48-72$ hours later. Both IGRA tests are based on detecting the release of the cytokine Interferon Gamma (IFN- $\psi$ ), which is produced in response to M. tuberculosis complex specific antigens, the early secretory antigenic target-6 (ESAT-6) and culture filtrate protein-10 (CFP-10). QantiFERON is an enzyme-linked immunosorbent assay (ELISA) test, T-SPOT.TB an immunospot assay. A number of studies have explored the test 
properties, usually against the gold standard of active TB and the test agreement (kappa). The sensitivity of these three tests is comparable (76-90\%), but the specificity of IGRA tests tends to be higher than TST (93-95\% vs. 57\%), due to the absence of cross-reactivity with environmental mycobacteria and BCG(47).

Whilst there is an abundant literature on sensitivity and specificity, the more important test property is the progression rate- the likelihood that a person with a positive test will go on to develop active TB, from the individual perspective, and the number need to treat to prevent one TB case (NNT) from the public health system perspective. Large cohort studies with sufficient follow up time are needed to answer this question. A number of systematic reviews have estimated progression rates: Rangaka et al found progression rates between 0.4-4.8 per 100 person years in IGRA positive individuals(48); Diel et al estimated a pooled progression rate of 2.7\% (95\% $\mathrm{Cl}, 2.3 \%-3.2 \%)$ and $1.5 \%(95 \% \mathrm{Cl}, 1.2 \%-1.7 \%)$ for IGRAs and TST respectively(49). In another meta-analysis Diel et al found progression rates between $8-15 \%$ and $2-3 \%$ over $19-24$ months for IGRAs and TST respectively(50). However, all of these reviews are based on a mixture of studies in different groups, often largely contacts of active cases. They also report on a mixture of settings, such as high and low incidence countries, which may partly explain differing results.

Review-level evidence examining LTBI progression rates in migrant populations is scarce. A systematic review of Campbell et al(51) included three studies on progression rates in migrants from high to low incidence countries: Maclntyre et al(52) reports five incident cases in a cohort of 437 TST positive, treatment naïve, Australia-bound refugees (1.1\%) over 5 years; Truong et al (53)found 9 cases in a cohort of 191 US-bound Tibetans (4.7\%) followed up over a mean of 19 
months; and Harstad(54) reported 8 cases amongst 236 Quantiferon positive, treatment naïve asylum seekers in Norway (3.4\%) followed up over 23-32 months. A cohort study reported up to 15.6\% reactivation rate over 15 years(55) in a TST positive treatment naïve South Asian population in England.

Robust evidence on reactivation rates, based on well-designed and large cohort studies, is required. However, it is fair to conclude that the PPV for all commercially available tests for LBTI is relatively low (about 1-15\%) in any at-risk population, including migrants, demonstrating the need to target programmes in order to optimise effectiveness and cost-effectiveness. Whilst efforts to limit screening to migrants from high incidence countries are common(56), a recent large cohort study identified other important risk factors of becoming an incident case, alongside increasing incidence in the country of origin, such as chest-X-Ray abnormalities (without active TB) and visa type(57). Operationalising these findings may help to improve the relatively low predictive value of LTBI tests and reduce the numbers needed to screen.

\section{Treatment regimens}

There have been a number of systematic reviews on the effectiveness of LTBI treatment. Currently used regimens include a 6-9 months monotherapy of isoniazid, a 3 months combination therapy of isoniazid and rifampicin and a 3-4 months monotherapy of rifampicin. All of these have good efficacy in trials. Smieja et al estimated a reduction of the relative risk (RR) for developing active TB in non-HIV infected persons treated with 6 months isoniazid as RR 0.40, (95\% Cl 0.31 to 0.52$)(58)$. More recently this has been confirmed by Stagg et al (OR 0.64, $\mathrm{Cl}$ 0.48-0.83)(59). Two further systematic reviews have recently emphasised the benefits of 
rifamycin-containing regimens. Sharma et al found an equivalent efficacy to prevent TB events between a 3-4 months rifampicin (3-4R), either as monotherapy or in combination with isoniazid, compared with 6 months isoniazid monotherapy. Sharma et al also identified significantly fewer hepatotoxicity events ( $\mathrm{RR} 0.12,95 \% \mathrm{Cl} 0.05$ to 0.30 ) and better treatment adherence for 3-4R monotherapy(60). Stagg et al confirmed these findings both in conventional and Bayesian network meta-analysis. The authors reported rifamycin containing regimes ranked amongst the most efficacious and least toxic of all (TB prevention for 3-4R compared with placebo had an OR of $0.41, \mathrm{Cl} 0.18$ to 0.86$)(59)$. Superior treatment adherence, inferior hepatotoxicity risk, and equivalent efficacy have been reported using once-weekly rifapentine regimens(61), and this regimen is recommended by the WHO. However, it is not licensed in Europe and in most other countries outside the US yet, a very relevant current barrier to more widespread use. It can be concluded that highly efficacious LTBI treatment regimens are available, although barriers to completion include the length and pill burden of treatments, adverse drug reactions, and the high mobility of migrants that correlates with a higher risk of defaulting from treatment.

\section{The screening care cascade}

For LTBI screening to be effective and cost-effective high rates of screening uptake and then subsequent completion of treatment are essential. A number of systematic reviews have recently explored behavioural, structural and programmatic aspects in detail. A systematic review by Alsdurf et al identified significant losses to follow up on every step of the care cascade - from screening uptake to treatment completion(62). In their meta-analysis the researchers analysed 70 independent cohorts, of which 12 were constituted by migrants, and found a testing uptake of $71.9 \%(95 \% \mathrm{Cl} 71.8-72.0)$ and a treatment completion rate of $18.8 \%(\mathrm{Cl} 16 \cdot 3-$ 
19.7). However, it is worth noting that this review contained a highly diverse range of contexts in low, middle and high-income countries, addressing different target populations, type of programmes and even tests used. Nevertheless, the main message is clear -getting persons with LTBI tested and treated remains a challenge. In their recent systematic review, Sandgren et al reported LTBI initiation rates among migrant populations ranging between $23-97 \%$ ( $n=4$ studies) and a range of 7-86\% LTBI treatment completion rate ( $n=5$ studies)(63). The authors considered the data too heterogeneous to present a pooled analysis but found higher completion rates associated with shorter regimens, a finding which is corroborated elsewhere in the literature $(61,64)$. A systematic review by Stuurman et al ( $n=23$ studies) showed that shorter treatment regimens and directly observed therapy correlated with treatment completion. Amongst migrant sub-populations ( $n=3$ studies) there was a generally positive effect of social interventions (such as education, adherence coaching, peer counselling, or cultural interventions), particularly if combined with the use of shorter regimens(65).

\section{Impact on host country epidemiology}

How effective LTBI screening will be and the magnitude of impact on the respective country epidemiology will depend on how well LTBI screening and treatment can be targeted and how well the programme can be operationalized, including ensuring high uptake and completion of treatment. There are no empiric studies which directly compare the effectiveness of an LTBI screening and treatment intervention with no screening, any estimation of impact must therefore be indirect. A number of mathematical modelling studies have looked at this question(66), however it is worth noting that parameterisation of these models is often based on observational studies of differing quality. 
A number of modelling studies have explored the effect of LTBI screening on the respective country incidence and often report a large impact compared with other interventions. Hill et al modelled the effect of different TB control interventions on TB incidence in the USA projecting over the next 50 years and concluded that "targeted testing and treatment of LTBI will be necessary (...) to achieve levels close to elimination in an acceptable timeframe" $(66)$. In the context of achieving the WHO End TB strategy goals, Houben et al have modelled a number of different interventions in South Africa, China and India and demonstrated that in countries such as China with a good TB programme performance and a relatively small epidemiological contribution of transmission to TB incidence, addressing LTBI systematically is key to further significant incidence reductions and achieving interim targets by 2025(67). Dye et al analysed the prospects of TB elimination by 2050 in four country scenarios - South Africa, China, India and the United States. Notwithstanding the importance and transmission reduction in high incidence settings, the authors also conclude that in HIV low prevalence settings "preventive therapy for infected people" will have to supplement efforts, outlining the practical challenges, and potential solutions in better biomarkers and shorter therapy regimens(68) .

There are only few country-specific studies, which directly quantify the expected impact of LTBI screening. Varughese et al estimate an $18.5 \%$ TB incidence reduction in Canada, if new migrants from countries of an incidence above 50 per 100,000 were screened and treated for LTBI(69). For Australia, Denholm et al estimated that an effective combination of LTBI screening and treatment would reduce incidence by about one third to half by 2050 with higher sensitivity tests and shorter treatment regimens leading to greater benefits. The numbers needed to screen varied by target population, screening test and treatment regimen between 136 and 427 per TB case prevented(70). 


\section{Cost Effectiveness of LTBI screening}

A number of studies have explored the cost effectiveness of LTBI screening, although none included the programmatic aspects (such as uptake) to a full extent. Whilst costs and gains of the programmes are context specific and dependent on the test used, the economic perspective, the target population, programme and treatment costs, most modelling studies have demonstrated cost effectiveness for example amongst migrant children in Canada(71) or among adults in the USA $(63,64)$. Cost-effectiveness is most commonly expressed as cost per case prevented, not cost per QALY. What is acceptable for a healthcare system varies - in the USA less than $\$ 100,000$ per QALY is acceptable, whereas in the UK the threshold is $£ 30,000$. These preferences will also determine whether an intervention is deemed cost-effective or not.

A number of modelling studies outline the importance of a targeted approach for screening migrants. Oxlade et al found that TST-based screening is only cost-effective in high-risk populations, with high reactivation rates (1.2-5\%) (74). Pareek and colleagues modelled costeffectiveness of screening in migrants for different incidence threshold and found that screening to an incidence threshold of 150 per 100,000 in the country of origin would allow detection of $92 \%$ of LTBI positives at a cost of $£ 20,818$ per case prevented (cost effective in the UK). Wingate et al examine the cost-effectiveness of pre-entry screening for LTBI and found this highly cost effective when targeting US-bound migrants from moderate to high incidence countries(41).

A few systematic reviews have summarised the cost-effectiveness evidence. Auguste et al included 10 cost-effectiveness studies in total ( 2 amongst migrants) in their review and found that among recent migrants TST alone was the most cost-effective strategy (incremental cost 
effectiveness ratio, ICER $£ 1$ 1,524 per QALY)(75). The key finding of the cost-effectiveness of TSTbased migrant screening has been corroborated elsewhere (76). This has to be balanced against potential overdiagnosis/overtreatment (due to the reduced specificity) and feasibility in programmatic screening and the practicalities including the need to return for reading. Nienhaus and colleagues reviewed 5 cost studies and 8 cost effectiveness studies and concluded that whilst the unit price of IGRA may be higher, this is offset by the reduced costs for investigation (including CXRs) and treatment in positive individuals (77). In another scoping review of economic evaluations on LTBI screening strategies for migrants, Zammarchi and colleagues identified nine studies, and concluded that LTBI screening was cost-effective according to seven of them. Two studies found that LTBI screening is cost-effective only if carried out in immigrants who are contacts of active TB cases. Findings of four studies support interferon gamma release assay as the most cost-effective test for LTBI screening in migrants(78). A recent systematic review of methods used for economic modelling concluded that methodological limitations and heterogeneity make comparisons and generalizations difficult(45).

Strengths and limitations

We present a narrative review. Differing from systematic reviews, our objectives and eligibility criteria were kept necessarily wide in order to provide a broad and informed overview of a complex area(79). We therefore included a range of populations, interventions, comparisons, outcomes and study designs allowing us to identify gaps for future research and inform the design of subsequent, more targeted systematic reviews on this topic. Our review was carried out systematically, but was limited to Medline-indexed English language papers, published in 
the past 15 years. We also provided a limited assessment about study quality and risk of bias, using an appropriate tool(10).

A key limitation to this paper is that rather than comprehensively describing which interventions provide the most effective and cost-effective methods of screening migrants for active and latent TB, we highlight key areas, which require further exploration using well-described systematic review methodology. Another key limitation is the quality of the underlying studies. There is significant variation in the type and size of study, the setting and their methodology, ranging from systematic reviews to small single setting observational studies. The overall poor quality of many underlying studies, as well as the limitations of the narrative nature of this review means that conclusions should be drawn with caution.

\section{Conclusions}

In conclusion, despite the above limitations it is likely that both screening for active and latent TB can be effective and cost effective if highly targeted and well implemented. There are a number of trade-offs and policy choices for all types of screening. Particularly in LTBI screening the behavioural factors may influence effectiveness and cost-effectiveness to a great extent and should be considered. An important example is the consideration of IGRAs for LTBI testing which, despite higher unit costs, could be more effective and cost-effective operationally and therefore lead to higher impact on the host countries' epidemiology. More evidence is needed, and improved monitoring and evaluation systems for LTBI may help to obtain appropriate data. There is an urgent need for high quality, operational research to use such data to evaluate 
effectiveness and cost effectiveness of the existing programmes in a more standardised way and inform future direction of screening and treatment approaches and there is also a need for systematic reviews to explore specific questions outlined here in further detail.

\section{Acknowledgments}

The authors would like to acknowledge the support of the National Institute for Health Research Health Protection Research Unit (NIHR HPRU) in Respiratory Infections at Imperial College London. 


\section{$\underline{\text { References }}$}

1. GBD 2015 Mortality and Causes of Death Collaborators. Global, regional, and national life expectancy, all-cause mortality, and cause-specific mortality for 249 causes of death, 1980-2015: a systematic analysis for the Global Burden of Disease Study 2015. Lancet Lond Engl. 2016 Oct 8;388(10053):1459-544.

2. The World Health Organization. Global Tuberculosis Report 2016. 2016.

3. The World Health Organization. The End TB Strategy. 2015.

4. European Centre for Disease Prevention and Control. Tuberculosis surveillance and monitoring in Europe 2016 [Internet]. Available from: http://ecdc.europa.eu/en/publications/Publications/ecdc-tuberculosissurveillance-monitoring-Europe-2016.pdf

5. Lönnroth K, Mor Z, Erkens C, Bruchfeld J, Nathavitharana R, van der Werf MJ, et al. Tuberculosis in migrants from endemic to low-incidence countries epidemiology, determinants and interventions. Int J Tuberc Lung Dis. 2017; in print.

6. Golub JE, Mohan CI, Comstock GW, Chaisson RE. Active case finding of tuberculosis: historical perspective and future prospects. Int J Tuberc Lung Dis Off J Int Union Tuberc Lung Dis. 2005 Nov;9(11):1183-203.

7. Abubakar I, Thomas HL, Morgan M, Anderson S, Zenner D, Cosford P. A collaborative strategy to tackle tuberculosis in England. Lancet. 2015 Jan 16;

8. Zenner D, Zumla A, Gill P, Cosford P, Abubakar I. Reversing the tide of the UK tuberculosis epidemic. The Lancet. 2013 Oct;382(9901):1311-2.

9. Kranzer K, Afnan-Holmes H, Tomlin K, Golub JE, Shapiro AE, Schaap A, et al. The benefits to communities and individuals of screening for active tuberculosis disease: a systematic review. Int J Tuberc Lung Dis Off J Int Union Tuberc Lung Dis. 2013 Apr;17(4):432-46.

10. Scottish Intercollegiate Guidelines Network (SIGN). A guideline developer's handbook (SIGN publication no. 50). [Internet]. 2015. Available from: http://www.sign.ac.uk

11. World Health Organization. WHO Expert Committee on Tuberculosis: ninth report. (WHO Technical Report Series, No. 552). [Internet]. 1974. Available from:

http://apps.who.int/iris/bitstream/10665/41095/1/WHO_TRS_552_eng.pdf

12. World Health Organization. Systematic screening for active tuberculosis

Principles and recommendations. WHO/HTM/TB/2013.04 [Internet]. 2013. 
Available from:

http://www.who.int/tb/publications/Final_TB_Screening_guidelines.pdf

13. Lönnroth K, Migliori GB, Abubakar I, D’Ambrosio L, de Vries G, Diel R, et al. Towards tuberculosis elimination: an action framework for low-incidence countries. Eur Respir J. 2015 Apr;45(4):928-52.

14. Jit M, Stagg HR, Aldridge RW, White PJ, Abubakar I, For the Find and Treat Evaluation Team. Dedicated outreach service for hard to reach patients with tuberculosis in London: observational study and economic evaluation. BMJ. 2011 Sep 13;343(sep13 5):d5376-d5376.

15. Klinkenberg E, Manissero D, Semenza JC, Verver S. Migrant tuberculosis screening in the EU/EEA: yield, coverage and limitations. Eur Respir J. 2009 Nov;34(5):1180-9.

16. Alvarez G, Gushulak B, Rumman K, Altpeter E, Chemtob D, Douglas P, et al. A comparative examination of tuberculosis immigration medical screening programs from selected countries with high immigration and low tuberculosis incidence rates. BMC Infect Dis. 2011 Jan 4;11(1):3.

17. Kunst H, Burman M, Arnesen TM, Fiebig L, Hergens M-P, Kalkouni R, et al. Tuberculosis and latent tuberculosis infection screening in migrants in Europe: comparative analysis of policies, surveillance systems and results. Int J Tuberc Lung Dis. 2017;in print.

18. Aldridge RW, Yates TA, Zenner D, White PJ, Abubakar I, Hayward AC. Pre-entry screening programmes for tuberculosis in migrants to low-incidence countries: a systematic review and meta-analysis. Lancet Infect Dis. 2014 Dec;14(12):1240-9.

19. Zenner D, Southern J, van Hest NAH, De Vries G, Stagg HR, Antoine D, et al. Active case finding for tuberculosis among high-risk groups in low-incidence countries. Int J Tuberc Lung Dis.

20. Van't Hoog AH, Onozaki I, Lonnroth K. Choosing algorithms for TB screening: a modelling study to compare yield, predictive value and diagnostic burden. BMC Infect Dis. 2014;14:532.

21. Liu Y, Posey DL, Cetron MS, Painter JA. Effect of a culture-based screening algorithm on tuberculosis incidence in immigrants and refugees bound for the United States: a population-based cross-sectional study. Ann Intern Med. 2015;162(6):420-8.

22. den Boon S, White NW, van Lill SWP, Borgdorff MW, Verver S, Lombard CJ, et al. An evaluation of symptom and chest radiographic screening in tuberculosis 
prevalence surveys. Int J Tuberc Lung Dis Off J Int Union Tuberc Lung Dis. 2006 Aug;10(8):876-82.

23. English RG, Bachmann MO, Bateman ED, Zwarenstein MF, Fairall LR, Bheekie A, et al. Diagnostic accuracy of an integrated respiratory guideline in identifying patients with respiratory symptoms requiring screening for pulmonary tuberculosis: a cross-sectional study. BMC Pulm Med. 2006 Aug 25;6:22.

24. van't Hoog AH, Williamson J, Sewe M, Mboya P, Odeny LO, Agaya JA, et al. Risk factors for excess mortality and death in adults with tuberculosis in Western Kenya. Int J Tuberc Lung Dis Off J Int Union Tuberc Lung Dis. 2012 Dec;16(12):1649-56.

25. Public Health England. Tuberculosis in England 2016 Report [Internet]. Available from: https://www.gov.uk/government/uploads/system/uploads/attachment_data /file/492431/TB_Annual_Report_v2.6_07012016.pdf

26. Napoli C, Dente MG, Kärki T, Riccardo F, Rossi P, Declich S. Screening for Infectious Diseases among Newly Arrived Migrants: Experiences and Practices in Non-EU Countries of the Mediterranean Basin and Black Sea. Int J Environ Res Public Health. 2015 Dec;12(12):15550-8.

27. Flynn M, Brown L, Tesfai A, Lauer T. Post-migration screening for active tuberculosis in Victoria, Australia. Int J Tuberc Lung Dis Off J Int Union Tuberc Lung Dis. 2012 Jan;16(1):50-4.

28. Centers for Disease Control and Prevention (CDC. Tuberculosis Screening and Treatment Technical Instructions (TB TIs) using Cultures and Directly Observed Therapy (DOT) for Panel Physicians. [Internet]. 2016. Available from: http://www.cdc.gov/immigrantrefugeehealth/exams/ti/panel/tuberculosispanel-technical-instructions.html

29. Douglas P, Posey DL, Zenner D, Robson J, Abubakar I, Giovinazzo G. Capacity strengthening through premigration TB screening programmes: IRHWG experiences. Int J Epidemiol. 2017;in print.

30. UK Visas and Immigration. UK Tuberculosis Technical Instructions. September 2013, version 6. [Internet]. Available from: https://www.gov.uk/government/uploads/system/uploads/attachment_data /file/245009/UK_tuberculosis_technical_instructions.pdf

31. Harling R, Pearce M, Chandrakumar M, Mueller K, Hayward A. Tuberculosis screening of asylum seekers: 1 years' experience at the Dover Induction Centres. Public Health. 11;121(11):822-7. 
32. Tafuri S, Martinelli D, Melpignano L, de Palma M, Quarto M, Prato R, et al. Tuberculosis screening in migrant reception centers: results of a 2009 Italian survey. Am J Infect Control. 2011 Aug;39(6):495-9.

33. Meier V, Artelt T, Cierpiol S, Gossner J, Scheithauer S. Tuberculosis in newly arrived asylum seekers: A prospective 12 month surveillance study at Friedland, Germany. Int J Hyg Environ Health. 2016 Jul 28;

34. Erkens C, Slump E, Kamphorst M, Keizer S, Gerven PJHJ van, Bwire R, et al. Coverage and yield of entry and follow-up screening for tuberculosis among new immigrants. Eur Respir J. 2008 Jul 1;32(1):153-61.

35. Coker RJ, Bell A, Pitman R, Hayward A, Watson J. Screening programmes for tuberculosis in new entrants across Europe. Int J Tuberc Lung Dis Off J Int Union Tuberc Lung Dis. 2004 Aug;8(8):1022-6.

36. Severi E, Maguire H, Ihekweazu C, Bickler G, Abubakar I. Outcomes analysis of new entrant screening for active tuberculosis in Heathrow and Gatwick airports, United Kingdom 2009/2010. BMC Infect Dis. 2016 Apr 22;16:178.

37. Arshad S, Bavan L, Gajari K, Paget SN, Baussano I. Active screening at entry for tuberculosis among new immigrants: a systematic review and meta-analysis. Eur Respir J. 2010;35(6):1336-45.

38. Aldridge RW, Zenner D, White PJ, Muzyamba MC, Loutet M, Dhavan P, et al. Prevalence of and risk factors for active tuberculosis in migrants screened before entry to the UK: a population-based cross-sectional study. Lancet Infect Dis [Internet]. 2016 Mar [cited 2016 Apr 27]; Available from: http://linkinghub.elsevier.com/retrieve/pii/S1473309916000724

39. Public Health England. UK pre-entry tuberculosis screening report 2015 [Internet]. Available from: https://www.gov.uk/government/uploads/system/uploads/attachment_data /file/555150/UK_pre-entry_tuberculosis_screening_2015_GTW230916.pdf

40. DASGUPTA K, SCHWARTZMAN K, MARCHAND R, TENNENBAUM TN, BRASSARD P, MENZIES D. Comparison of Cost-Effectiveness of Tuberculosis Screening of Close Contacts and Foreign-Born Populations. Am J Respir Crit Care Med. 2000 Dec 1;162(6):2079-86.

41. Wingate LT, Coleman MS, Posey DL, Zhou W, Olson CK, Maskery B, et al. CostEffectiveness of Screening and Treating Foreign-Born Students for Tuberculosis before Entering the United States. PLoS ONE. 2015;10(4):e0124116.

42. Dasgupta K, Menzies D. Cost-effectiveness of tuberculosis control strategies among immigrants and refugees. Eur Respir J. 2005 Jun;25(6):1107-16. 
43. Alon Y. The yield of tuberculosis screening of undocumented migrants from the Horn of Africa based on chest radiography. 2015;

44. Denholm JT. Immigration screening for latent tuberculosis infection. Med J Aust. 2013;199(10).

45. Shedrawy J. Methodological considerations for economic modelling of latent tuberculosis screening in immigrants to low-TB incidence countries: a systematic review. Int J Tuberc Lung Dis. in print.

46. Fok A, Numata Y, Schulzer M, FitzGerald MJ. Risk factors for clustering of tuberculosis cases: a systematic review of population-based molecular epidemiology studies. Int J Tuberc Lung Dis Off J Int Union Tuberc Lung Dis. 2008 May;12(5):480-92.

47. Pai M, Zwerling A, Menzies D. Systematic review: T-cell-based assays for the diagnosis of latent tuberculosis infection: an update. Ann Intern Med. 2008 Aug 5;149(3):177-84.

48. Rangaka MX, Wilkinson KA, Glynn JR, Ling D, Menzies D, Mwansa-Kambafwile J, et al. Predictive value of interferon-? release assays for incident active tuberculosis: a systematic review and meta-analysis. Lancet Infect Dis. 2012 Jan;12(1):45-55.

49. Diel R, Loddenkemper R, Nienhaus A. Predictive value of interferon- $\gamma$ release assays and tuberculin skin testing for progression from latent TB infection to disease state: a meta-analysis. Chest. 2012 Jul;142(1):63-75.

50. Diel R, Goletti D, Ferrara G, Bothamley G, Cirillo D, Kampmann B, et al. Interferon- $\gamma$ release assays for the diagnosis of latent Mycobacterium tuberculosis infection: a systematic review and meta-analysis. Eur Respir J Off J Eur Soc Clin Respir Physiol. 2011 Jan;37(1):88-99.

51. Campbell JR, Krot J, Elwood K, Cook V, Marra F. A systematic review on TST and IGRA tests used for diagnosis of LTBI in immigrants. Mol Diagn Ther. 2015 Feb;19(1):9-24.

52. MacIntyre CR, Plant AJ. Longitudinal incidence of tuberculosis in South-East Asian refugees after re-settlement. Int J Tuberc Lung Dis Off J Int Union Tuberc Lung Dis. 1999 Apr;3(4):287-93.

53. Truong DH, Hedemark LL, Mickman JK, Mosher LB, Dietrich SE, Lowry PW. TUberculosis among tibetan immigrants from india and nepal in minnesota, 1992-1995. JAMA. 1997 Mar 5;277(9):735-8. 
54. Harstad I, Jacobsen GW, Heldal E, Winje BA, Vahedi S, Helvik A-S, et al. The role of entry screening in case finding of tuberculosis among asylum seekers in Norway. BMC Public Health. 2010;10:670-670.

55. Choudhury I, West C, Ormerod LP. The outcome of a cohort of Tuberculin positive predominantly South Asian New Entrants aged 16-34 to the United Kingdom: Blackburn 1989- to 2000. Journal or Public Health (in press);

56. Pareek M, Baussano I, Abubakar I, Dye C, Lalvani A. Evaluation of immigrant tuberculosis screening in industrialized countries. Emerg Infect Dis. 2012 Sep;18(9):1422-9.

57. Aldridge RW, Zenner D, White PJ, Williamson EJ, Muzyamba MC, Dhavan P, et al. Tuberculosis in migrants moving from high-incidence to low-incidence countries: a population-based cohort study of 519955 migrants screened before entry to England, Wales, and Northern Ireland. Lancet Lond Engl. 2016 Oct 10;

58. Smieja MJ, Marchetti CA, Cook DJ, Smaill FM. Isoniazid for preventing tuberculosis in non-HIV infected persons. Cochrane Database Syst Rev Online. 2000;(2):CD001363.

59. Stagg HR, Zenner D, Harris RJ, Muñoz L, Lipman MC, Abubakar I. Treatment of Latent Tuberculosis Infection: A Network Meta-analysis. Ann Intern Med. 2014 Sep 16;161(6):419-28.

60. Sharma SK, Sharma A, Kadhiravan T, Tharyan P. Rifamycins (rifampicin, rifabutin and rifapentine) compared to isoniazid for preventing tuberculosis in HIV-negative people at risk of active TB. Cochrane Database Syst Rev. 2013;7:CD007545.

61. Sterling TR, Villarino ME, Borisov AS, Shang N, Gordin F, Bliven-Sizemore E, et al. Three months of rifapentine and isoniazid for latent tuberculosis infection. N Engl J Med. 2011 Dec 8;365(23):2155-66.

62. Alsdurf H, Hill PC, Matteelli A, Getahun H, Menzies D. The cascade of care in diagnosis and treatment of latent tuberculosis infection: a systematic review and meta-analysis. Lancet Infect Dis. 2016 Aug 10;

63. Sandgren A, Vonk Noordegraaf-Schouten M, van Kessel F, Stuurman A, OordtSpeets A, van der Werf MJ. Initiation and completion rates for latent tuberculosis infection treatment: a systematic review. BMC Infect Dis. 2016 May 17;16:204.

64. Hirsch-Moverman Y, Daftary A, Franks J, Colson PW. Adherence to treatment for latent tuberculosis infection: systematic review of studies in the US and 
Canada. Int J Tuberc Lung Dis Off J Int Union Tuberc Lung Dis. 2008 Nov;12(11):1235-54.

65. Stuurman AL, Vonk Noordegraaf-Schouten M, van Kessel F, Oordt-Speets AM, Sandgren A, van der Werf MJ. Interventions for improving adherence to treatment for latent tuberculosis infection: a systematic review. BMC Infect Dis. 2016 Jun 8;16:257.

66. Hill AN, Becerra JE, Castro KG. Modelling tuberculosis trends in the USA. Epidemiol Infect. 2012 Oct;140(10):1862-72.

67. Houben RMGJ, Menzies NA, Sumner T, Huynh GH, Arinaminpathy N, GoldhaberFiebert JD, et al. Feasibility of achieving the 2025 WHO global tuberculosis targets in South Africa, China, and India: a combined analysis of 11 mathematical models. Lancet Glob Health. 2016 Nov;4(11):e806-15.

68. Dye C, Glaziou P, Floyd K, Raviglione M. Prospects for Tuberculosis Elimination. Annu Rev Public Health. 2013;34(1):271-86.

69. Varughese MB, Langlois-Klassen D, Long R, Li M. Preventing tuberculosis in the foreign-born population of Canada: a mathematical modelling study. Int J Tuberc Lung Dis. 2014 Apr 1;18(4):405-12.

70. Denholm JT, McBryde ES. Can Australia eliminate TB? Modelling immigration strategies for reaching MDG targets in a low-transmission setting. Aust N Z J Public Health. 2014 Feb 1;38(1):78-82.

71. Brassard P, Steensma C, Cadieux L, Lands LC. Evaluation of a school-based tuberculosis-screening program and associate investigation targeting recently immigrated children in a low-burden country. Pediatrics. 2006 Feb;117(2):e148-56.

72. Khan K, Muennig P, Behta M, Zivin JG. Global Drug-Resistance Patterns and the Management of Latent Tuberculosis Infection in Immigrants to the United States. N Engl J Med. 2002;347(23):1850-9.

73. Linas BP, Wong AY, Freedberg KA, Horsburgh CR. Priorities for screening and treatment of latent tuberculosis infection in the United States. Am J Respir Crit Care Med. 2011 Sep 1;184(5):590-601.

74. Oxlade O, Schwartzman K, Menzies D. Interferon-gamma release assays and TB screening in high-income countries: a cost-effectiveness analysis. Int J Tuberc Lung Dis Off J Int Union Tuberc Lung Dis. 2007 Jan;11(1):16-26.

75. Auguste P, Tsertsvadze A, Pink J, Court R, Seedat F, Gurung T, et al. Accurate diagnosis of latent tuberculosis in children, people who are immunocompromised or at risk from immunosuppression and recent arrivals 
from countries with a high incidence of tuberculosis: systematic review and economic evaluation. Health Technol Assess Winch Engl. 2016 May;20(38):1678.

76. Campbell JR, Sasitharan T, Marra F. A Systematic Review of Studies Evaluating the Cost Utility of Screening High-Risk Populations for Latent Tuberculosis Infection. Appl Health Econ Health Policy. 2015 Aug;13(4):325-40.

77. Nienhaus A, Schablon A, Costa JT, Diel R. Systematic review of cost and costeffectiveness of different TB-screening strategies. BMC Health Serv Res. 2011;11:247.

78. Zammarchi L, Casadei G, Strohmeyer M, Bartalesi F, Liendo C, Matteelli A, et al. A scoping review of cost-effectiveness of screening and treatment for latent tubercolosis infection in migrants from high-incidence countries. BMC Health Serv Res. 2015 Sep 24;15:412.

79. Armstrong R, Hall BJ, Doyle J, Waters E. Cochrane Update. "Scoping the scope" of a cochrane review. J Public Health Oxf Engl. 2011 Mar;33(1):147-50.

80. Trauer JM, Krause VL. Assessment and management of latent tuberculosis infection in a refugee population in the Northern Territory. Med J Aust. 2011;194(11):579.

81. Mulder C, Mulleners B, Borgdorff MW, van Leth F. Predictive Value of the Tuberculin Skin Test among Newly Arriving Immigrants. PLoS ONE. 2013 Mar 27;8(3):e60130.

82. Pareek M, Bond M, Shorey J, Seneviratne S, Guy M, White P, et al. Communitybased evaluation of immigrant tuberculosis screening using interferon $\gamma$ release assays and tuberculin skin testing: observational study and economic analysis. Thorax. 2013 Mar 1;68(3):230-9.

83. CARVALHO ACC, SALERI N, EL-HAMAD I, TEDOLDI S, CAPONE S, PEZZOLI MC, et al. Completion of screening for latent tuberculosis infection among immigrants. Epidemiol Infect. 2005;133(1):179-85.

84. Pareek M, Watson JP, Ormerod LP, Kon OM, Woltmann G, White PJ, et al. Screening of immigrants in the UK for imported latent tuberculosis: a multicentre cohort study and cost-effectiveness analysis. Lancet Infect Dis. 2011;11(6):435-44.

85. Bodenmann P, Vaucher P, Wolff H, Favrat B, de Tribolet F, Masserey E, et al. Screening for latent tuberculosis infection among undocumented immigrants in Swiss healthcare centres; a descriptive exploratory study. BMC Infect Dis. 2009;9(1):1-8. 
86. Bua A, Cubeddu M, Piras D, Delogu R, Zanetti S, Molicotti P. Tuberculosis screening among asylum seekers in Sardinia. J Public Health Oxf. 2016 Jan 24;

87. Lucas M, Nicol P, McKinnon E, Whidborne R, Lucas A, Thambiran A, et al. A prospective large-scale study of methods for the detection of latent Mycobacterium tuberculosis infection in refugee children. Thorax. 2010 May 1;65(5):442-8.

88. Flynn M, Brown L, Tesfai A, Lauer T. Post-migration screening for active tuberculosis in Victoria, Australia. Int J Tuberc Lung Dis. 2012 Jan;16(1):50-4.

89. Johnsen NL, Steen TW, Meyer H, Heldal E, Skarpaas IJK, June GB. Cohort analysis of asylum seekers in Oslo, Norway, 1987-1995: effectiveness of screening at entry and TB incidence in subsequent years. Int J Tuberc Lung Dis. //;9(1):37-42.

90. Khan K, Hirji MM, Miniota J, Hu W, Wang J, Gardam M, et al. Domestic impact of tuberculosis screening among new immigrants to Ontario, Canada. Cmaj. 2015 Nov 3;187(16):E473-81.

91. Liu Y, Weinberg MS, Ortega LS, Painter JA, Maloney SA. Overseas Screening for Tuberculosis in U.S.-Bound Immigrants and Refugees. N Engl J Med. 2009;360(23):2406-15.

92. Mathez C, Bangala Y, Bady P, Zellweger JP. Active screening for pulmonary tuberculosis among immigrants by chest $\mathrm{x}$-ray at the Swiss border. Swiss Med Wkly. 2007 Nov 17;137(45-46):649-54.

93. Chang $S$, Wheeler LS, Farrell KP. Public health impact of targeted tuberculosis screening in public schools. Am J Public Health. 2002;92(12):1942-5.

94. Baussano I, Mercadante S, Pareek M, Lalvani A, Bugiani M. High rates of Mycobacterium tuberculosis among socially marginalized immigrants in lowincidence area, 1991-2010, Italy. Emerg Infect Dis. 2013;19(9):1437-45.

95. Minodier P, Lamarre V, Carle M-E, Blais D, Ovetchkine P, Tapiero B. Evaluation of a school-based program for diagnosis and treatment of latent tuberculosis infection in immigrant children. J Infect Public Health. 2010;3(2):67-75.

96. Levesque J, Dongier P, Brassard P, Allard R. Acceptance of screening and completion of treatment for latent tuberculosis infection among refugee claimants in Canada. Int J Tuberc Lung Dis. 2004;8(6):711-7.

97. Li J, Munsiff SS, Agerton TB. Prevalence of Tuberculin Skin Test Positivity in Clinical Population in New York City. J Immigr Minor Health. 2010;12(6):81622. 
98. Mulder C, van Deutekom H, Huisman EM, Toumanian S, Koster BF, MeijerVeldman W, et al. Role of the QuantiFERON®-TB Gold In-Tube assay in screening new immigrants for tuberculosis infection. Eur Respir J. 2012;40(6):1443-9.

99. Lifson AR, Thai D, O'Fallon A, Mills WA, Hang K. Prevalence of tuberculosis, hepatitis $B$ virus, and intestinal parasitic infections among refugees to Minnesota. Public Health Rep. 2002;117(1):69-77.

100. Desale M, Bringardner P, Fitzgerald S, Page K, Shah M. Intensified case-finding for latent tuberculosis infection among the Baltimore city Hispanic population. J Immigr Minor Health. 2013;15(4):680-5.

101. Mor Z, Lerman Y, Leventhal A. Pre-immigration screening process and pulmonary tuberculosis among Ethiopian migrants in Israel. Eur Respir J. 2008 Aug 1;32(2):413-8.

102. Varkey P, Jerath AU, Bagniewski SM, Lesnick TG. The epidemiology of tuberculosis among primary refugee arrivals in Minnesota between 1997 and 2001. J Travel Med. 2007;14(1):1-8.

103. Tafuri S, Martinelli D, Melpignano L, de Palma M, Quarto M, Prato R, et al. Tuberculosis screening in migrant reception centers: results of a 2009 Italian survey. Am J Infect Control. 2011 Aug;39(6):495-9.

104. King K, Douglas PJ, Beath K. Is premigration health screening for tuberculosis worthwhile. Med J Aust. 2011;195(9):534-7.

105. Maloney SA, Fielding KL, Laserson KF, et al. Assessing the performance of overseas tuberculosis screening programs: A study among us-bound immigrants in vietnam. Arch Intern Med. 2006;166(2):234-40.

106. Mor Z, Leventhal A, Weiler-Ravell D, Peled N, Lerman Y. Chest Radiography Validity in Screening Pulmonary Tuberculosis in Immigrants From a HighBurden Country. Respir Care. 2012 Jul 1;57(7):1137-44.

107. Plant AJ, Watkins RE, Motus N, Jones W, O'Rourke T, Streeton J, et al. Results of tuberculosis screening in applicants for migration in Vietnam and Cambodia. Int J Tuberc Lung Dis. //;9(2):157-63.

108. Aldridge RW, Zenner D, White PJ, Muzyamba MC, Loutet M, Dhavan P, et al. Prevalence of and risk factors for active tuberculosis in migrants screened before entry to the UK: a population-based cross-sectional study. Lancet Infect Dis. 2016;

109. Alvarez GG, Gushulak B, Rumman KA, Altpeter E, Chemtob D, Douglas P, et al. A comparative examination of tuberculosis immigration medical screening 
programs from selected countries with high immigration and low tuberculosis incidence rates. BMC Infect Dis. 2011;11(1):1-12.

110. Losi M, Bergamini B, Venturelli C, Del Giovane C, Sighinolfi G, Rumpaneisi F, et al. Tuberculosis infection in foreign-born children: a screening survey based on skin and blood testing [Short communication]. Int J Tuberc Lung Dis. 2011;15(9):1182-4.

111. Padovese V, Egidi A, Melillo TF, Farrugia B, Carabot P, Didero D, et al. Prevalence of latent tuberculosis, syphilis, hepatitis B and C among asylum seekers in Malta. J Public Health. 2013;fdt036.

112. Yanni EA, Naoum M, Odeh N, Han P, Coleman M, Burke H. The Health Profile and Chronic Diseases Comorbidities of US-Bound Iraqi Refugees Screened by the International Organization for Migration in Jordan: 2007-2009. J Immigr Minor Health. 2013;15(1):1-9.

113. Winje BA, Oftung F, Korsvold GE, Mannsåker T, Jeppesen AS, Harstad I, et al. Screening for tuberculosis infection among newly arrived asylum seekers: Comparison of QuantiFERON®TB Gold with tuberculin skin test. BMC Infect Dis. 2008;8(1):1-10.

114. Hladun O, Grau A, Esteban E, Jansà JM. Results from screening immigrants of low-income countries: data from a public primary health care. J Travel Med. 2014;21(2):92-8.

115. Hardy AB, Varma R, Collyns T, Moffitt SJ, Mullarkey C, Watson JP. Costeffectiveness of the NICE guidelines for screening for latent tuberculosis infection: the QuantiFERON-TB Gold IGRA alone is more cost-effective for immigrants from high burden countries. Thorax. 2010 Feb 1;65(2):178-80.

116. Linas BP, Wong AY, Freedberg KA, Horsburgh CR. Priorities for Screening and Treatment of Latent Tuberculosis Infection in the United States. Am J Respir Crit Care Med. 2011 Sep 1;184(5):590-601.

117. Haukaas FS, Arnesen TM, Winje BA, Aas E. Immigrant screening for latent tuberculosis in Norway: a cost-effectiveness analysis. Eur J Health Econ. 2016;1-11.

118. Oxlade O, Schwartzman K, Menzies D. Interferon-gamma release assays and TB screening in high-income countries: a cost-effectiveness analysis. Int J Tuberc Lung Dis. 2007;11(1):16-26.

119. Porco TC, Lewis B, Marseille E, Grinsdale J, Flood JM, Royce SE. Costeffectiveness of tuberculosis evaluation and treatment of newly-arrived immigrants. BMC Public Health. 2006;6(1):1-15. 
120. La'Marcus TW, Coleman MS, de la Motte Hurst C, Semple M, Zhou W, Cetron MS, et al. A cost-benefit analysis of a proposed overseas refugee latent tuberculosis infection screening and treatment program. BMC Public Health. 2015;15(1):1.

121. Auguste P, Tsertsvadze A, Pink J, Seedat F, Gurung T, Freeman K, et al. Accurate diagnosis of latent tuberculosis in children, people who are immunocompromised or at risk from immunosuppression and recent arrivals from countries with a high incidence of tuberculosis: systematic review and economic evaluation. Health Technol Assess Winch Engl. 2016;20(38):1-678.

122. SCHWARTZMAN K, MENZIES D. Tuberculosis Screening of Immigrants to Low-Prevalence Countries. Am J Respir Crit Care Med. 2000 Mar 1;161(3):780-9. 


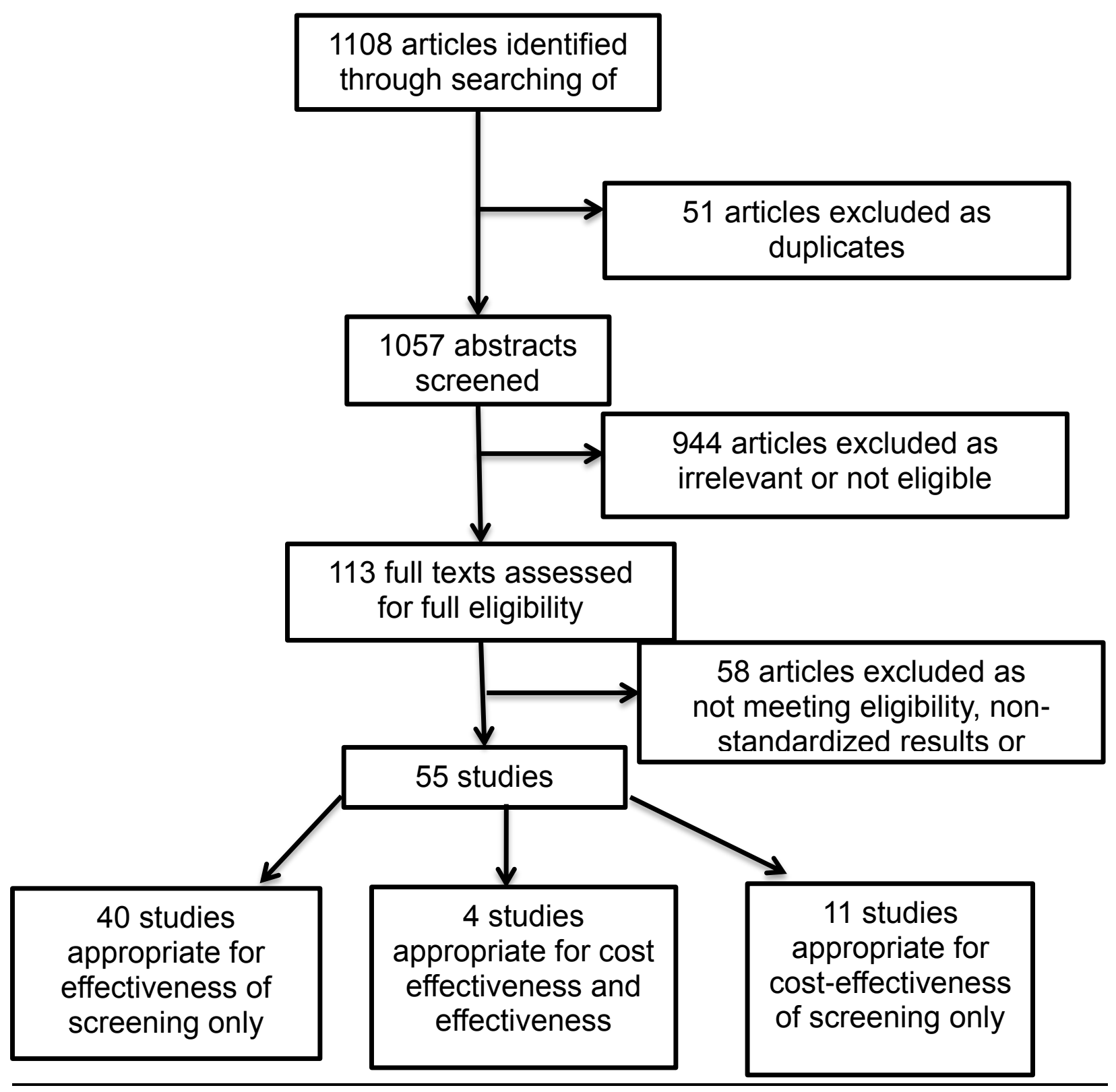

Figure 1 - inclusion of studies 


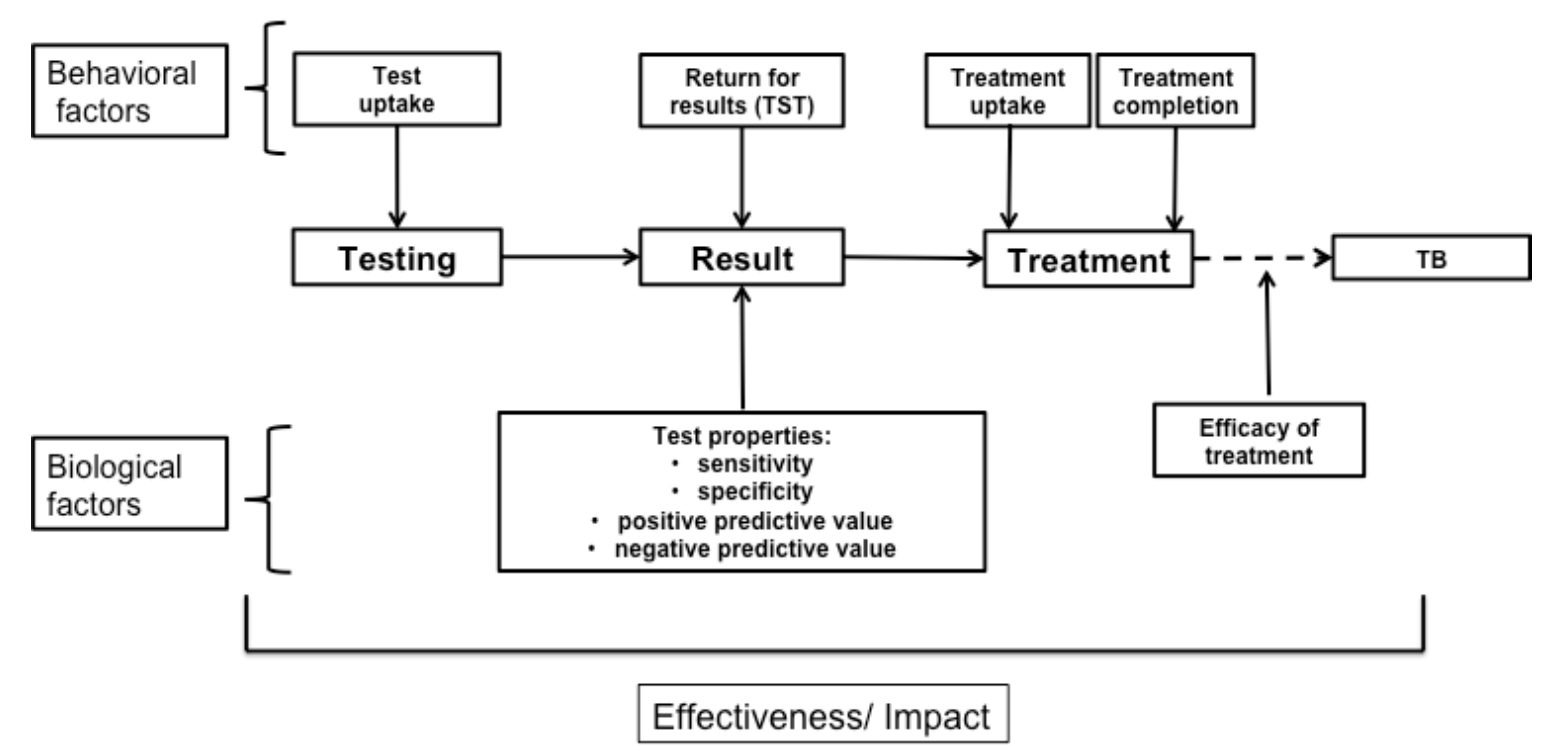

Figure 2 - conceptual model for LTBI screening 
appendix - search terms

The database was searched using the following search phrases:

“Tuberculosis AND (screening OR mass screening OR prevalence OR yield OR incidence) AND

(migrants OR new arrivals OR refugees OR asylum seekers OR immigrants) “

and

“Tuberculosis AND (screening OR mass screening OR prevalence OR yield OR incidence) AND

(cost-effect* OR cost-bene* OR “Cost- Benefit Analysis) AND (migrants OR new arrivals OR

refugees OR asylum seekers OR immigrants)“ 


\begin{tabular}{|c|c|c|c|c|c|c|c|c|c|c|}
\hline Author & Year & Study design & $\begin{array}{l}\text { Screening } \\
\text { setting }\end{array}$ & $\begin{array}{l}\text { Host country } \\
\text { of new } \\
\text { migrants }\end{array}$ & Type of migrant & $\begin{array}{l}\text { Active } \\
\text { (pulmonary } \\
\text { unless stated } \\
\text { otherwise) or } \\
\text { Latent }\end{array}$ & $\begin{array}{l}\text { Primary } \\
\text { screening } \\
\text { method }\end{array}$ & Yield & $\begin{array}{l}\text { Total population } \\
\text { size/sample size } \\
\text { (Coverage) }\end{array}$ & $\begin{array}{l}\text { SIGN score } \\
(+/++)\end{array}$ \\
\hline \multirow{2}{*}{$\begin{array}{l}\text { Campbell } \\
\text { et al (51) }\end{array}$} & \multirow[b]{2}{*}{2015} & \multirow[b]{2}{*}{ Meta-Analysis } & \multirow{2}{*}{$\begin{array}{l}\text { Post } \\
\text { entry }\end{array}$} & \multirow[b]{2}{*}{ Multiple } & \multirow[b]{2}{*}{ All migrants } & \multirow[b]{2}{*}{ Latent } & TST or & $40.7 \%(1232 / 3028)$ & Unknown & \multirow[b]{2}{*}{+} \\
\hline & & & & & & & IGRA & $32.2 \%(974 / 3028)$ & & \\
\hline $\begin{array}{l}\text { Arshad et } \\
\text { al (37) }\end{array}$ & 2010 & Meta-Analysis & On entry & Multiple & All migrants & Active & $\begin{array}{l}\text { CXR and sputum } \\
\text { smear and } \\
\text { culture }\end{array}$ & 0.035 per 100,000 & Unknown & ++ \\
\hline $\begin{array}{l}\text { Trauer and } \\
\text { Krause } \\
(80)\end{array}$ & 2011 & $\begin{array}{l}\text { Prospective } \\
\text { cohort study }\end{array}$ & $\begin{array}{l}\text { Post } \\
\text { entry }\end{array}$ & Australia & All refugees & Latent & TST & $31.9 \%(146 / 458)$ & 465 (98.5\%) & + \\
\hline \multirow{2}{*}{$\begin{array}{l}\text { Mulder et } \\
\text { al (81) }\end{array}$} & \multirow{2}{*}{2013} & \multirow{2}{*}{$\begin{array}{l}\text { Prospective } \\
\text { cohort study }\end{array}$} & \multirow{2}{*}{$\begin{array}{l}\text { Post } \\
\text { entry }\end{array}$} & \multirow{2}{*}{ Netherlands } & \multirow{2}{*}{ All migrants } & \multirow{2}{*}{ Latent } & \multirow{2}{*}{ TST } & $\begin{array}{l}\text { TST > 10mm: } 42.6 \% \\
\text { (273/643) }\end{array}$ & \multirow{2}{*}{$2569(25.1 \%)$} & \multirow{2}{*}{+} \\
\hline & & & & & & & & $\begin{array}{l}\text { TST >15mm : } 23.0 \% \\
(145 / 643)\end{array}$ & & \\
\hline \multirow{3}{*}{$\begin{array}{l}\text { Pareek et } \\
\text { al (82) }\end{array}$} & \multirow{3}{*}{2013} & \multirow{3}{*}{$\begin{array}{l}\text { Prospective } \\
\text { cohort study }\end{array}$} & \multirow{3}{*}{$\begin{array}{l}\text { Post } \\
\text { entry }\end{array}$} & \multirow{3}{*}{ UK } & \multirow{3}{*}{$\begin{array}{l}\text { All symptomatic } \\
\text { migrants. } \\
\text { Asymptomatic } \\
\text { migrants from } \\
\text { countries with TB } \\
\text { incidence }>40 \text { per } \\
100,000\end{array}$} & \multirow{3}{*}{ Latent } & QFT-GIT and & $6.6 \%(38 / 229)$ & \multirow{3}{*}{306 (75.5\%) } & \multirow{3}{*}{ ++ } \\
\hline & & & & & & & T-spot and & $22.5 \%(36 / 160)$ & & \\
\hline & & & & & & & TST & $30.3 \%(53 / 175)$ & & \\
\hline $\begin{array}{l}\text { Carvalho } \\
\text { et al (83) }\end{array}$ & 2005 & $\begin{array}{l}\text { Prospective } \\
\text { cohort study }\end{array}$ & $\begin{array}{l}\text { Post } \\
\text { entry }\end{array}$ & Italy & $\begin{array}{l}\text { Migrants from } \\
\text { countries with TB } \\
\text { incidence }>50 \text { per } \\
100,000\end{array}$ & Latent & TST & $58.2 \%(124 / 213)$ & (1613) $13.2 \%$ & ++ \\
\hline $\begin{array}{l}\text { Meier et al } \\
\text { (33) }\end{array}$ & 2016 & $\begin{array}{l}\text { Prospective } \\
\text { cohort study }\end{array}$ & $\begin{array}{l}\text { Post } \\
\text { entry }\end{array}$ & Germany & Asylum seekers & Active & Sputum culture & $\begin{array}{l}93 \text { per } 100,000 \\
(11 / 11773)\end{array}$ & $11773(100 \%)$ & + \\
\hline $\begin{array}{l}\text { Pareek et } \\
\text { al (84) }\end{array}$ & 2011 & $\begin{array}{l}\text { Prospective } \\
\text { cohort study }\end{array}$ & $\begin{array}{l}\text { Post } \\
\text { entry }\end{array}$ & UK & $\begin{array}{l}\text { All Migrants referred } \\
\text { from on entry } \\
\text { screening }\end{array}$ & Latent & IGRA & $19.9 \%(245 / 1229)$ & $1633(75.3 \%)$ & ++ \\
\hline $\begin{array}{l}\text { Bodenman } \\
\mathrm{n} \text { et al (85) }\end{array}$ & 2009 & $\begin{array}{l}\text { Prospective } \\
\text { cohort study }\end{array}$ & $\begin{array}{l}\text { Post } \\
\text { entry }\end{array}$ & Switzerland & $\begin{array}{l}\text { Undocumented } \\
\text { migrants }\end{array}$ & $\begin{array}{l}\text { Active and } \\
\text { latent }\end{array}$ & $\begin{array}{l}\text { Active: sputum } \\
\text { smear and } \\
\text { culture }\end{array}$ & $\begin{array}{l}1600 \text { per } 100,000 \\
(2 / 125)\end{array}$ & $161(77.6 \%)$ & + \\
\hline
\end{tabular}




\begin{tabular}{|c|c|c|c|c|c|c|c|c|c|c|}
\hline & & & & & & & Latent: IGRA & $19.2 \%(24 / 125)$ & $161(77.6 \%)$ & \\
\hline $\begin{array}{c}\text { Bua et al } \\
(86)\end{array}$ & 2006 & $\begin{array}{l}\text { Prospective } \\
\text { cohort study }\end{array}$ & $\begin{array}{l}\text { Post } \\
\text { entry }\end{array}$ & Italy & $\begin{array}{l}\text { Migrants from Sub } \\
\text { Saharan Africa, } \\
\text { Bangladesh or } \\
\text { Pakistan }\end{array}$ & Latent & $\begin{array}{l}\text { TST and } \\
\text { QFT-GIT }\end{array}$ & $36.9 \%(40 / 149)$ & $\begin{array}{l}\text { Unknown } \\
\text { Unknown }\end{array}$ & + \\
\hline $\begin{array}{l}\text { Lucas et al } \\
\quad(87)\end{array}$ & 2010 & $\begin{array}{l}\text { Prospective } \\
\text { cohort study }\end{array}$ & $\begin{array}{l}\text { Post } \\
\text { entry }\end{array}$ & USA & $\begin{array}{l}\text { Refugee children } \\
\text { from Africa or Burma }\end{array}$ & Latent & $\begin{array}{l}\text { TST or } \\
\text { QFT-GIT or } \\
\text { T-spot }\end{array}$ & $\begin{array}{l}17.8 \%(54 / 304) \\
9.8 \%(45 / 460) \\
9.0 \%(38 / 420)\end{array}$ & Unknown & + \\
\hline $\begin{array}{l}\text { Flynn et al } \\
(88)\end{array}$ & 2012 & $\begin{array}{l}\text { Retrospective } \\
\text { cohort study }\end{array}$ & $\begin{array}{l}\text { Post } \\
\text { entry }\end{array}$ & Australia & All migrants & Active & CXR & $\begin{array}{l}420 \text { per } 100,000 \\
(79 / 18801)\end{array}$ & Unknown & + \\
\hline $\begin{array}{l}\text { Johnsen et } \\
\text { al (89) }\end{array}$ & 2005 & $\begin{array}{l}\text { Retrospective } \\
\text { cohort study }\end{array}$ & On entry & Norway & Asylum seekers & $\begin{array}{l}\text { Active } \\
\text { including extra } \\
\text { pulmonary }\end{array}$ & MMR scan & $\begin{array}{l}110 \text { per } 100,000 \\
(22 / 19912)\end{array}$ & 23644 (84\%) & + \\
\hline $\begin{array}{l}\text { Khan et al } \\
(90)\end{array}$ & 2015 & $\begin{array}{l}\text { Retrospective } \\
\text { cohort study }\end{array}$ & Pre entry & Canada & All migrants & Active & Sputum culture & $\begin{array}{l}106 \text { per } 100,000 \text { (380 } \\
/ 357085)\end{array}$ & 357085 (100\%) & + \\
\hline $\begin{array}{l}\text { Liu et al } \\
\text { (91) }\end{array}$ & 2009 & $\begin{array}{l}\text { Retrospective } \\
\text { cohort study }\end{array}$ & Pre entry & USA & All migrants & Active & $\begin{array}{l}\text { Active: CXR and } \\
\text { sputum smear }\end{array}$ & $\begin{array}{l}961 \text { per } 100,000 \\
(26075 / 2714223)^{* *}\end{array}$ & $26075(100 \%)$ & + \\
\hline $\begin{array}{l}\text { Mathez et } \\
\text { al (92) }\end{array}$ & 2007 & $\begin{array}{l}\text { Retrospective } \\
\text { cohort study }\end{array}$ & Pre entry & Switzerland & All adult migrants & Active & $\begin{array}{l}\text { Sputum smear } \\
\text { and culture }\end{array}$ & $\begin{array}{l}556 \text { per } 100,000 \\
(50 / 8995)\end{array}$ & 8995 (100\%) & + \\
\hline
\end{tabular}




\begin{tabular}{|c|c|c|c|c|c|c|c|c|c|c|}
\hline $\begin{array}{l}\text { Brassard et } \\
\text { al (71) }\end{array}$ & 2006 & $\begin{array}{l}\text { Retrospective } \\
\text { cohort study }\end{array}$ & $\begin{array}{l}\text { Post } \\
\text { entry }\end{array}$ & Canada & Migrant children & Latent & TST & $21 \%(542 / 2525)$ & $3710(68 \%)$ & + \\
\hline $\begin{array}{l}\text { Chang et al } \\
\text { (93) }\end{array}$ & 2002 & $\begin{array}{l}\text { Retrospective } \\
\text { cohort study }\end{array}$ & $\begin{array}{l}\text { Post } \\
\text { entry }\end{array}$ & USA & All migrant students & Latent & TST & $16.4 \%(116 / 706)$ & (706)100\% & + \\
\hline \multirow{2}{*}{$\begin{array}{l}\text { Baussanno } \\
\text { et al (94) }\end{array}$} & \multirow[t]{2}{*}{2013} & \multirow{2}{*}{$\begin{array}{l}\text { Retrospective } \\
\text { cohort study }\end{array}$} & \multirow{2}{*}{$\begin{array}{l}\text { Post } \\
\text { entry }\end{array}$} & \multirow[t]{2}{*}{ Italy } & \multirow{2}{*}{$\begin{array}{l}\text { Socially marginalised } \\
\text { migrants (at social } \\
\text { care centres) }\end{array}$} & \multirow{2}{*}{$\begin{array}{l}\text { Active and } \\
\text { latent }\end{array}$} & $\begin{array}{l}\text { Sputum smear } \\
\text { and culture }\end{array}$ & $\begin{array}{l}2719 \text { per } 100,000 \\
(744 / 27,358)\end{array}$ & \multirow{2}{*}{$\begin{array}{l}\text { Unknown } \\
\text { Unknown }\end{array}$} & \multirow[t]{2}{*}{+} \\
\hline & & & & & & & TST & $34.6 \%(9183 / 26554)$ & & \\
\hline $\begin{array}{l}\text { Minodier } \\
\text { et al (95) }\end{array}$ & 2010 & $\begin{array}{l}\text { Retrospective } \\
\text { cohort study }\end{array}$ & $\begin{array}{l}\text { Post } \\
\text { entry }\end{array}$ & Canada & Migrant children & Latent & TST and CXR & $22.7 \%(777 / 3401)$ & 4375 (82.3\%) & + \\
\hline $\begin{array}{l}\text { Levesque } \\
\text { et al (96) }\end{array}$ & 2004 & $\begin{array}{l}\text { Retrospective } \\
\text { cohort study }\end{array}$ & $\begin{array}{l}\text { Post } \\
\text { entry }\end{array}$ & Canada & Asylum seekers & Latent & TST & $21.6 \%(49 / 227)$ & $582(55.5 \%)$ & + \\
\hline Li et al (97) & 2010 & $\begin{array}{l}\text { Retrospective } \\
\text { cohort study }\end{array}$ & $\begin{array}{l}\text { Post } \\
\text { entry }\end{array}$ & USA & All migrants & Latent & TST & $\begin{array}{l}39.5 \% \text { (crude numbers } \\
\text { not reported) }\end{array}$ & $51637(90.1 \%)$ & + \\
\hline $\begin{array}{l}\text { Mulder et } \\
\text { al (98) }\end{array}$ & 2012 & $\begin{array}{l}\text { Retrospective } \\
\text { cohort study }\end{array}$ & $\begin{array}{l}\text { Post } \\
\text { entry }\end{array}$ & Australia & All migrants & Latent & QFT-GIT & $24 \%(128 / 541)$ & Unknown & + \\
\hline $\begin{array}{l}\text { Harling et } \\
\text { al (31) }\end{array}$ & 2007 & $\begin{array}{l}\text { Retrospective } \\
\text { cohort study }\end{array}$ & On-entry & UK & Asylum seekers & Active & $\begin{array}{l}\text { Bacteriologically } \\
\text { confirmed }\end{array}$ & 70 per $100,000(3 / 4275)$ & 4563 (94\%) & + \\
\hline \multirow{2}{*}{$\begin{array}{l}\text { Lifson et al } \\
\qquad(99)\end{array}$} & \multirow[b]{2}{*}{2002} & \multirow{2}{*}{$\begin{array}{l}\text { Retrospective } \\
\text { cohort study }\end{array}$} & \multirow{2}{*}{$\begin{array}{l}\text { Post } \\
\text { entry }\end{array}$} & \multirow[b]{2}{*}{ USA } & \multirow[b]{2}{*}{ All refugees } & \multirow{2}{*}{$\begin{array}{l}\text { Active and } \\
\text { Latent }\end{array}$} & Latent: TST & $48.6 \%(1145 / 2545)$ & \multirow[t]{2}{*}{ (3914) 65\% } & \\
\hline & & & & & & & $\begin{array}{l}\text { Active: CXR and } \\
\text { sputum culture }\end{array}$ & 0 per $100,000(0 / 2545)$ & & + \\
\hline $\begin{array}{l}\text { Desale et } \\
\text { al (100) }\end{array}$ & 2013 & $\begin{array}{l}\text { Retrospective } \\
\text { cross sectional } \\
\text { study }\end{array}$ & $\begin{array}{l}\text { Post } \\
\text { entry }\end{array}$ & USA & Hispanic migrants & Latent & TST & $41.9 \%(164 / 391)$ & $81.80 \%$ & + \\
\hline $\begin{array}{l}\text { Mor et al } \\
(101)\end{array}$ & 2008 & $\begin{array}{l}\text { Retrospective } \\
\text { cohort study }\end{array}$ & $\begin{array}{l}\text { Pre and } \\
\text { post } \\
\text { entry }\end{array}$ & Israel & Ethiopian migrants & Active & $\begin{array}{l}\text { Sputum smear } \\
\text { and culture }\end{array}$ & $\begin{array}{l}\text { Pre entry: } 324 \text { per } \\
\text { 100,000 person years }\end{array}$ & $24051(61 \%)$ & + \\
\hline
\end{tabular}




\begin{tabular}{|c|c|c|c|c|c|c|c|c|c|c|}
\hline & & & & & & & & $\begin{array}{l}\text { Post entry: } 267 \text { per } \\
\text { 100,000 person years }\end{array}$ & 24051 (39\%) & \\
\hline \multirow{2}{*}{$\begin{array}{l}\text { Varkey et } \\
\text { al (102) }\end{array}$} & \multirow{2}{*}{2007} & \multirow{2}{*}{$\begin{array}{l}\text { Retrospective } \\
\text { cohort study }\end{array}$} & \multirow{2}{*}{$\begin{array}{l}\text { Post } \\
\text { entry }\end{array}$} & \multirow{2}{*}{ USA } & \multirow{2}{*}{ All refugees } & \multirow{2}{*}{$\begin{array}{l}\text { Active } \\
\text { (including } \\
\text { extra } \\
\text { pulmonary) } \\
\text { and latent }\end{array}$} & $\begin{array}{l}\text { Active: Drug } \\
\text { records }\end{array}$ & $\begin{array}{l}800 \text { per } 100,000 \\
(116 / 13,866)\end{array}$ & $13866(100 \%)$ & \multirow{2}{*}{+} \\
\hline & & & & & & & Latent: TST & $50.7 \%(4990 / 9842)$ & 13866 (70.9\%) & \\
\hline \multirow{2}{*}{$\begin{array}{l}\text { Harstad et } \\
\text { al (54) }\end{array}$} & \multirow{2}{*}{2010} & \multirow{2}{*}{$\begin{array}{l}\text { Retrospective } \\
\text { cohort study }\end{array}$} & \multirow{2}{*}{$\begin{array}{l}\text { On and } \\
\text { post } \\
\text { entry }\end{array}$} & \multirow{2}{*}{ Norway } & \multirow{2}{*}{ Asylum seekers } & \multirow{2}{*}{$\begin{array}{l}\text { Active } \\
\text { including extra } \\
\text { pulmonary }\end{array}$} & \multirow{2}{*}{$\begin{array}{l}\text { Abnormal CXR } \\
\text { or TST }\end{array}$} & $\begin{array}{l}\text { On entry: } 671 \text { per } \\
100,000(15 / 2237)\end{array}$ & 4643 (49\%) & \multirow[t]{2}{*}{+} \\
\hline & & & & & & & & $\begin{array}{l}\text { Post entry: } 581 \text { per } \\
100,000(13 / 2237)\end{array}$ & 4643 (49\%) & \\
\hline $\begin{array}{l}\text { Tafuri et al } \\
(103)\end{array}$ & 2011 & $\begin{array}{l}\text { Cross sectional } \\
\text { study }\end{array}$ & $\begin{array}{l}\text { Post } \\
\text { entry }\end{array}$ & Italy & Asylum seekers & Active & TST & 814 per $100,000(8 / 982)$ & 1007 (97.5\%) & + \\
\hline $\begin{array}{l}\text { King et al } \\
(104)\end{array}$ & 2011 & $\begin{array}{l}\text { Cross sectional } \\
\text { study }\end{array}$ & Pre entry & Australia & All migrants & Active & $\begin{array}{l}\text { Sputum smear } \\
\text { and culture }\end{array}$ & $\begin{array}{l}137 \text { per } 100,000 \\
(519 / 378939)\end{array}$ & 378939 (100\%) & ++ \\
\hline $\begin{array}{l}\text { Maloney } \\
\text { et al (105) }\end{array}$ & 2006 & $\begin{array}{l}\text { Cross sectional } \\
\text { study }\end{array}$ & Pre entry & USA & Vietnamese migrants & Active & $\begin{array}{l}\text { Sputum smear } \\
\text { and culture }\end{array}$ & $\begin{array}{l}582 \text { per } 100,000 \\
(183 / 14098)\end{array}$ & $14098(100 \%)$ & ++ \\
\hline $\begin{array}{l}\text { Mor et al } \\
(103)\end{array}$ & 2012 & $\begin{array}{l}\text { Cross sectional } \\
\text { study }\end{array}$ & Pre entry & Israel & Ethiopian migrants & Active & Sputum culture & $\begin{array}{l}305 \text { per } 100,000 \\
(43 / 13379)\end{array}$ & $13379(100 \%)$ & ++ \\
\hline $\begin{array}{l}\text { Plant et al } \\
(107)\end{array}$ & 2005 & $\begin{array}{l}\text { Cross sectional } \\
\text { study }\end{array}$ & Pre entry & Australia & $\begin{array}{l}\text { Vietnamese and } \\
\text { Cambodian migrants }\end{array}$ & Active & $\begin{array}{l}\text { Sputum smear } \\
\text { and culture }\end{array}$ & $\begin{array}{l}598 \text { per } 100,000 \\
(36 / 6018)\end{array}$ & Unknown & + \\
\hline $\begin{array}{l}\text { Aldridge et } \\
\text { al (108) }\end{array}$ & 2016 & $\begin{array}{l}\text { Cross sectional } \\
\text { study }\end{array}$ & Pre entry & UK & $\begin{array}{l}\text { Migrants from } \\
\text { countries with } \\
\text { incidence }>40 \text { per } \\
100,000\end{array}$ & Active & $\begin{array}{l}\text { Sputum smear } \\
\text { and culture }\end{array}$ & $\begin{array}{l}92 \text { per } 100,000 \\
(439 / 476455\end{array}$ & $692362(68.6 \%)$ & ++ \\
\hline $\begin{array}{l}\text { Liu et al } \\
\text { (21) }\end{array}$ & 2015 & $\begin{array}{l}\text { Cross sectional } \\
\text { study }\end{array}$ & Pre entry & USA & All migrants & Active & $\begin{array}{l}\text { Sputum smear } \\
\text { and culture }\end{array}$ & $\begin{array}{l}258 \text { per } 100,000 \\
(4032 / 1561460)\end{array}$ & $1561406(100 \%)$ & ++ \\
\hline
\end{tabular}




\begin{tabular}{|c|c|c|c|c|c|c|c|c|c|c|}
\hline $\begin{array}{l}\text { Alvarez et } \\
\text { al (109) }\end{array}$ & 2011 & $\begin{array}{l}\text { Cross- } \\
\text { Sectional } \\
\text { study* }\end{array}$ & $\begin{array}{l}\text { Post, on } \\
\text { and pre } \\
\text { entry } \\
\text { screening }\end{array}$ & Multiple & Varied & Active & Varied & $\begin{array}{l}\text { (per 100,000) } \\
\text { Canada:53.6 France 70; } \\
\text { Jordan: } 153 \text {; } \\
\text { Netherlands } 105 ; \\
\text { Switzerland } 122\end{array}$ & Unknown & 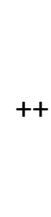 \\
\hline \multirow{4}{*}{$\begin{array}{l}\text { Losi et } \\
\text { al (110) }\end{array}$} & \multirow{4}{*}{2011} & \multirow{4}{*}{$\begin{array}{l}\text { Cross } \\
\text { sectional study }\end{array}$} & \multirow{4}{*}{$\begin{array}{l}\text { Post } \\
\text { entry }\end{array}$} & \multirow{4}{*}{ Italy } & \multirow{4}{*}{ Migrant children } & \multirow{4}{*}{$\begin{array}{l}\text { Active and } \\
\text { latent }\end{array}$} & $\begin{array}{l}\text { Active: Sputum } \\
\text { smear and } \\
\text { culture }\end{array}$ & 600 per $100,000(4 / 621)$ & \multirow{4}{*}{ Unknown } & \multirow{4}{*}{+} \\
\hline & & & & & & & \multirow{3}{*}{$\begin{array}{l}\text { Latent: QFT-GIT } \\
\text { and TST }\end{array}$} & $\begin{array}{l}\text { QFT-GIT: } 34.5 \%(80 / 232) \\
\text { of which }\end{array}$ & & \\
\hline & & & & & & & & $\begin{array}{l}\text { TST >10mm: } 82.5 \% \\
(50 / 80)\end{array}$ & & \\
\hline & & & & & & & & $\begin{array}{l}\text { QFT-GIT negative and } \\
\text { TST >10mm: } 35.5 \% \\
(54 / 152)\end{array}$ & & \\
\hline \multirow[t]{2}{*}{$\begin{array}{l}\text { Padovese } \\
\text { et al (111) }\end{array}$} & \multirow[t]{2}{*}{2013} & \multirow[t]{2}{*}{$\begin{array}{l}\text { Cross sectional } \\
\text { study }\end{array}$} & \multirow[t]{2}{*}{$\begin{array}{l}\text { Post } \\
\text { entry }\end{array}$} & \multirow[t]{2}{*}{ Malta } & \multirow[t]{2}{*}{ All Migrants } & \multirow[t]{2}{*}{$\begin{array}{l}\text { Active and } \\
\text { Latent }\end{array}$} & Active: IGRA & $\begin{array}{l}7661 \text { per } 100,000 \\
(19 / 214)\end{array}$ & \multirow[t]{2}{*}{$\begin{array}{l}500 \text { (Estimated } \\
\text { coverage:16.6\%) }\end{array}$} & \multirow[t]{2}{*}{+} \\
\hline & & & & & & & Latent: TST & $45.0 \%(225 / 500)$ & & \\
\hline \multirow[t]{2}{*}{$\begin{array}{l}\text { Yanni et al } \\
\text { (112) }\end{array}$} & \multirow[t]{2}{*}{2013} & \multirow[t]{2}{*}{$\begin{array}{l}\text { Cross sectional } \\
\text { study }\end{array}$} & \multirow[t]{2}{*}{ Pre entry } & \multirow[t]{2}{*}{ USA } & \multirow[t]{2}{*}{ Iraqi refugees } & \multirow[t]{2}{*}{$\begin{array}{l}\text { Active and } \\
\text { latent }\end{array}$} & \multirow[t]{2}{*}{$\begin{array}{l}\text { Any from: } \\
\text { medical history, } \\
\text { physical } \\
\text { examination, } \\
\text { CXR sputum } \\
\text { smear and } \\
\text { culture }\end{array}$} & $\begin{array}{l}\text { Active: } 7 \text { per } 100,000 \\
(1 / 14077)\end{array}$ & 18990 (74.1\%) & ++ \\
\hline & & & & & & & & $\begin{array}{l}\text { Latent: } 1.8 \% \\
(251 / 13669)\end{array}$ & $18990(72 \%)$ & \\
\hline \multirow[t]{2}{*}{$\begin{array}{l}\text { Winje et al } \\
(113)\end{array}$} & \multirow[t]{2}{*}{2008} & \multirow[t]{2}{*}{$\begin{array}{l}\text { Cross sectional } \\
\text { study }\end{array}$} & \multirow[t]{2}{*}{$\begin{array}{l}\text { Post } \\
\text { entry }\end{array}$} & \multirow[t]{2}{*}{ Norway } & \multirow[t]{2}{*}{ Asylum seekers } & \multirow[t]{2}{*}{ Latent } & TST and & $50.4 \%(460 / 912)$ & \multirow[t]{2}{*}{$2813(33.7 \%)$} & \multirow[t]{2}{*}{+} \\
\hline & & & & & & & QFT-GIT & $28.9 \%(264 / 912)$ & & \\
\hline
\end{tabular}




\begin{tabular}{|c|c|c|c|c|c|c|c|c|c|c|}
\hline \multirow{2}{*}{$\begin{array}{l}\text { Hladun et } \\
\text { al (114) }\end{array}$} & \multirow[t]{2}{*}{2014} & \multirow{2}{*}{$\begin{array}{l}\text { Cross sectional } \\
\text { study }\end{array}$} & \multirow{2}{*}{$\begin{array}{l}\text { Post } \\
\text { entry }\end{array}$} & \multirow[t]{2}{*}{ Spain } & \multirow{2}{*}{$\begin{array}{l}\text { Migrants from low } \\
\text { and middle income } \\
\text { countries }\end{array}$} & \multirow{2}{*}{$\begin{array}{l}\text { Active and } \\
\text { latent }\end{array}$} & Active: CXR & $\begin{array}{l}5782 \text { per } 100,000 \\
(17 / 294)\end{array}$ & \multirow[t]{2}{*}{ Unknown } & \multirow[t]{2}{*}{+} \\
\hline & & & & & & & Latent: TST & $28.1 \%(87 / 309)$ & & \\
\hline $\begin{array}{l}\text { Erkens et } \\
\text { al (34) }\end{array}$ & 2008 & $\begin{array}{l}\text { Retrospective } \\
\text { cohort study }\end{array}$ & $\begin{array}{l}\text { On entry } \\
\text { and post } \\
\text { entry } \\
\text { follow up }\end{array}$ & $\begin{array}{l}\text { The } \\
\text { Netherlands }\end{array}$ & $\begin{array}{l}\text { Migrants from non- } \\
\text { western countries } \\
\text { staying for }>3 \\
\text { months. Excluding } \\
\text { asylum seekers }\end{array}$ & Active & $\begin{array}{l}\text { Active: CXR } \\
\text { followed by } \\
\text { bacteriology }\end{array}$ & $\begin{array}{l}\text { On entry: } 119 \text { per } \\
100,000 \text { ( } 81 / 68122) \text { on } \\
\text { entry } \\
\text { Post entry } 9,37 \text { and } 97 \\
\text { per } 100,000 \text { for } \\
\text { migrants from countries } \\
\text { with incidence of }<100 \text {, } \\
100-200 \text { and }>200 \text { per } \\
100,000 \text { respectively }\end{array}$ & $\begin{array}{l}\text { On entry: not } \\
\text { reported } \\
\text { Post entry: } 59 \% \\
\text { to } 34 \% \text { ( } 2 \text { nd to } \\
5 \text { th round) }\end{array}$ & ++ \\
\hline
\end{tabular}

Note: All sputum smear and culture tests were performed following an abnormal chest X-ray.

* Survey of immigration practices in 16 low incident high migration countries.

Notes for methodology: SIGN methodology indicates: ++ High quality/low bias, + Acceptable/low bias.

SIGN methodology states that retrospective cohort studies and single centre studies can receive no higher than + (acceptable/low bias) which explains the large number of acceptable retrospective cohort studies.

SIGN methodology does not provide a checklist for cross-sectional studies. Therefore the SIGN study was adapted for cross sectional studies using the cohort study checklist. Cross sectional studies could not score higher than + (acceptable/low bias).

\begin{tabular}{|c|c|c|c|c|c|c|c|c|c|c|c|c|c|}
\hline Author & Year & Country & $\begin{array}{l}\text { Active/Latent } \\
\text { (pulmonary } \\
\text { unless } \\
\text { specified) }\end{array}$ & $\begin{array}{l}\text { Type of } \\
\text { Economic } \\
\text { Evaluation }\end{array}$ & $\begin{array}{l}\text { Data } \\
\text { source }\end{array}$ & Perspective & $\begin{array}{l}\text { Model } \\
\text { Horizon } \\
\text { Discount } \\
\text { rate }\end{array}$ & $\begin{array}{l}\text { Cost } \\
\text { description }\end{array}$ & $\begin{array}{l}\text { Population } \\
\text { screened/ } \\
\text { Screening } \\
\text { method }\end{array}$ & Differential costs & ICER & $\begin{array}{l}\text { TB cases } \\
\text { averted or } \\
\text { identified }\end{array}$ & $\begin{array}{l}\text { SIGN } \\
\text { score } \\
(++/+)\end{array}$ \\
\hline \multirow[t]{2}{*}{$\begin{array}{l}\text { Brassard } \\
\text { et al (71) }\end{array}$} & \multirow[t]{2}{*}{2006} & \multirow[t]{2}{*}{ Canada } & \multirow[t]{2}{*}{ Latent } & \multirow[t]{2}{*}{ CBA } & \multirow[t]{2}{*}{$\begin{array}{l}\text { Clinical } \\
\text { trial }\end{array}$} & \multirow[t]{2}{*}{$\begin{array}{l}\text { Health care } \\
\text { payer }\end{array}$} & \multirow[t]{2}{*}{ No } & \multirow{2}{*}{$\begin{array}{l}\text { All labour } \\
\text { costs } \\
\text { (nurses, } \\
\text { doctors) and } \\
\text { material } \\
\text { costs (e.g. } \\
\text { swabs, } \\
\text { educational } \\
\text { booklets) }\end{array}$} & $\begin{array}{l}\text { TST: Migrant } \\
\text { children }\end{array}$ & $\begin{array}{l}\text { Total savings: } \\
\$ 242,432\end{array}$ & & 25.6 & \multirow[t]{2}{*}{++} \\
\hline & & & & & & & & & $\begin{array}{l}\text { TST: Migrant } \\
\text { children and if } \\
\text { positive, } \\
\text { contacts }\end{array}$ & $\begin{array}{l}\text { Total savings: } \\
\$ 328,722\end{array}$ & & 36.1 & \\
\hline
\end{tabular}




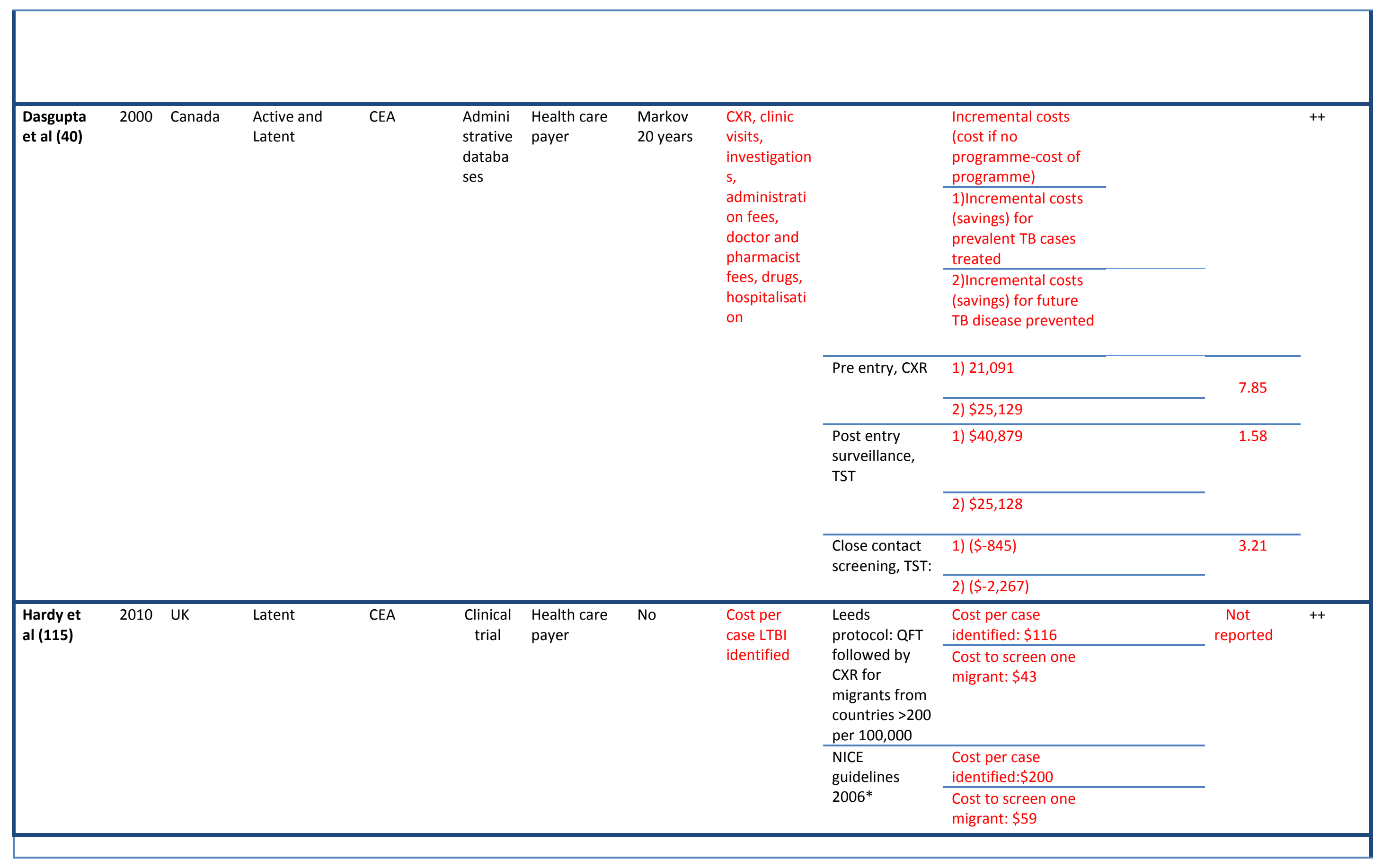




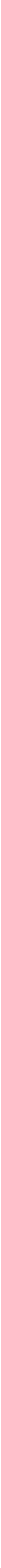




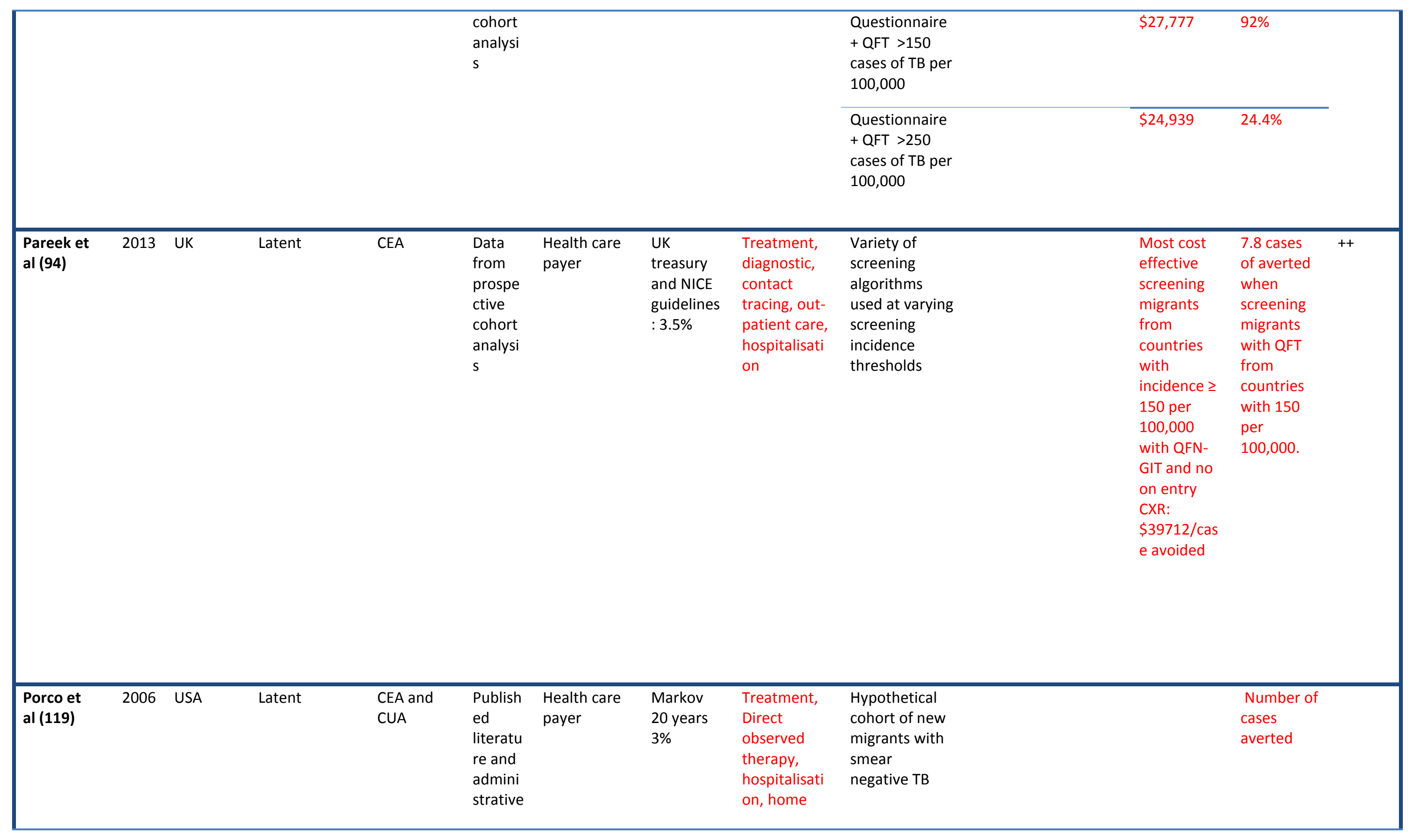




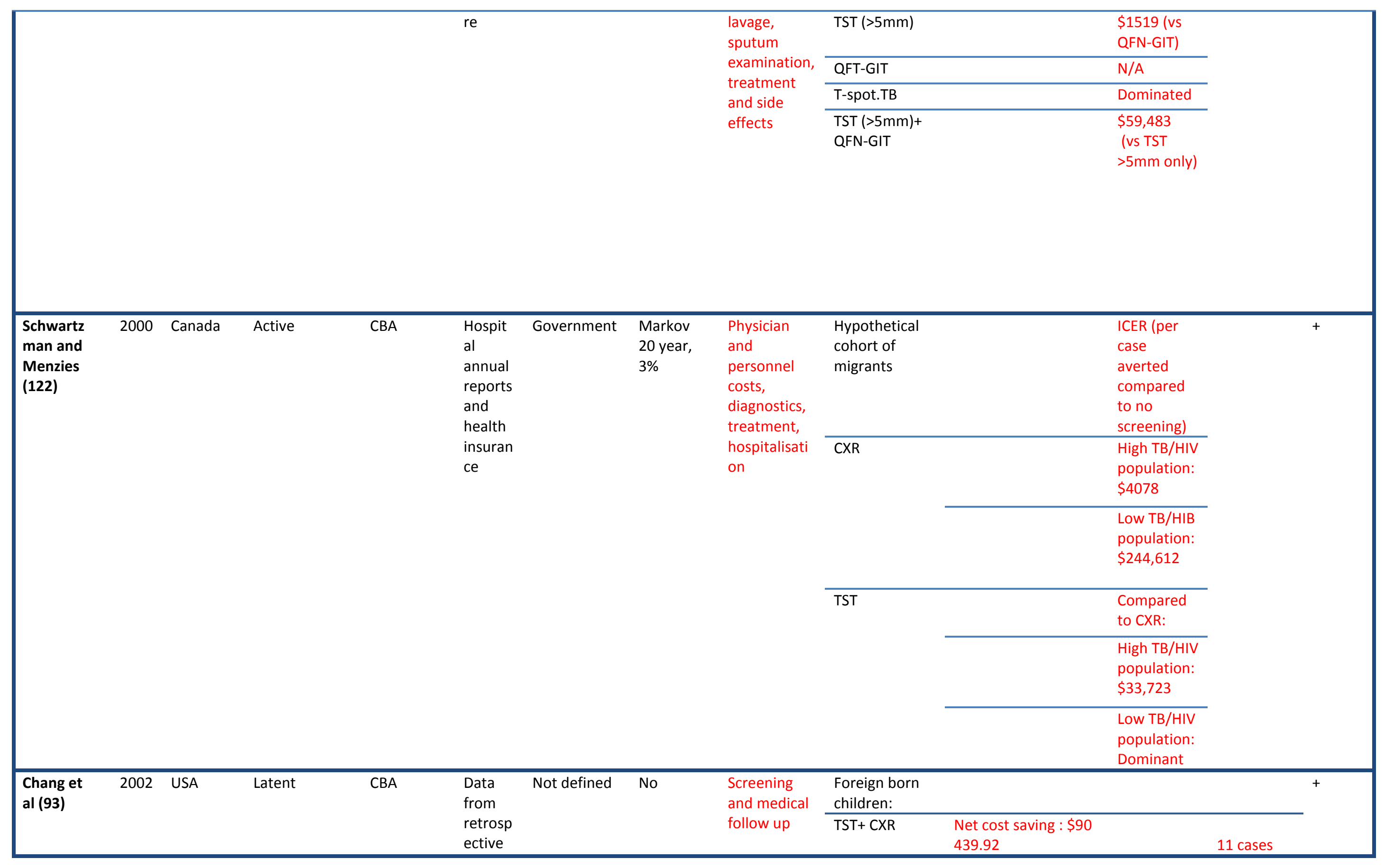




\begin{tabular}{|c|c|c|c|c|c|c|c|c|c|c|c|c|}
\hline & & & & & $\begin{array}{l}\text { cohort } \\
\text { analysi } \\
\text { s }\end{array}$ & & & & & & averted & \\
\hline \multirow[t]{3}{*}{$\begin{array}{l}\text { Wingate } \\
\text { et al (41) }\end{array}$} & \multirow{3}{*}{\multicolumn{2}{|c|}{2015 USA }} & \multirow[t]{3}{*}{ Active } & \multirow[t]{3}{*}{ CEA } & \multirow[t]{3}{*}{$\begin{array}{l}\text { Online } \\
\text { databa } \\
\text { ses }\end{array}$} & \multirow[t]{3}{*}{ Societal } & \multirow[t]{3}{*}{$\begin{array}{l}\text { N/A (costs } \\
\text { calculated } \\
\text { for first } \\
\text { year only) }\end{array}$} & \multirow{3}{*}{$\begin{array}{l}\text { Student } \\
\text { opportunity } \\
\text { costs, } \\
\text { hospitalisati } \\
\text { on, } \\
\text { treatment, } \\
\text { diagnostics, } \\
\text { lost tuition } \\
\text { fees for } \\
\text { universities, } \\
\text { burden to } \\
\text { insurers }\end{array}$} & $\begin{array}{l}\text { Students from } \\
\text { China, } \\
\text { Germany or } \\
\text { India. }\end{array}$ & $\begin{array}{l}\text { ICER per } \\
\text { case } \\
\text { averted } \\
\text { (USD) }\end{array}$ & \multirow[t]{3}{*}{$\begin{array}{l}\text { Total: } 157 \\
\text { cases } \\
\text { averted }\end{array}$} & \multirow[t]{3}{*}{++} \\
\hline & & & & & & & & & \multirow{2}{*}{$\begin{array}{l}\text { CXR followed } \\
\text { by sputum } \\
\text { smear and } \\
\text { culture }\end{array}$} & $\begin{array}{l}\text { China \$ } \\
23,098\end{array}$ & & \\
\hline & & & & & & & & & & $\begin{array}{l}\text { India: } \\
\$ 15,681\end{array}$ & & \\
\hline
\end{tabular}

*NICE guidelines 2006 : CXR in all immigrants from countries with TB incidence $>40$ per 100,000 and $>16$ years, TST if $<16$ years or $<35$ years from Sub Saharan Africa or from countries $>500$ per 100,000. QTF - GIT in TST positive to confirm LTBI.

+_Hypothetical cohort >18 years old entering USA from China, Philippines, S. Korean Vietnam, Asia and Pacific India, S.Asia, Mexico, Haiti, Latin America and Caribbean

‡_Risk groups include recent immigrant adults and children, foreign-born residents living in the U.S. for more than five years (stratified by age), close contact adults and children, HIV-infected

individuals, the homeless, injection drug users, former prisoners, gastrectomy patients, underweight patients, and persons with silicosis, diabetes, and end-stage renal disease.

Abbreviations: CBA- Cost Benefit Analysis; CUA- Cost Utility Analysis; CEA-Cost Effectiveness Analysis, CXR- Chest X-Ray

Notes for methodology: SIGN methodology indicates: ++ High quality/low bias, + Acceptable/low bias.

All costings were first converted to 2017 prices taking into account inflation using http://fxtop.com/. Costings were then converted into US Dollar on 21/03/2017 using http://www.ukforex.co.uk/currency-converter.

Table 3

Number of studies and TB case yield ranges for different types of screening and settings.

\begin{tabular}{|l|l|l|l|l|}
\cline { 2 - 5 } & \multicolumn{2}{|l|}{ Active } & Latent \\
\cline { 2 - 5 } & $\begin{array}{l}\text { Number of } \\
\text { studies } \\
\text { identified }\end{array}$ & Range (per 100,000) & $\begin{array}{l}\text { Number of studies } \\
\text { identified }\end{array}$ & Range (\%) \\
\hline Post entry & 13 & $0-7661$ & 23 & $9-82.5$ \\
\hline Pre entry & 11 & $7-961$ & 1 & 1.8 \\
\hline On entry & 5 & $0.035-671$ & 0 & 0 \\
\hline
\end{tabular}


*It was not possible to further stratify by migrant type due to the heterogeneity of the screening criteria 